\title{
BİST'te İşlem Gören Tekstil, Giyim Eşyası ve Deri Sektörü İşletmelerinin Altman-Z Skor Yöntemi İle Finansal Başarısızlık Tahmini \\ (Financial Failure Estimation of Textile, Clothing and Leather Industry Businesses Traded on BİST With Altman-Z Score Method)
}

\section{Meral EROL FIDAN iD a}

a Bilecik Şeyh Edebali Üniversitesi, İktisadi ve İdari Bilimler Fakültesi, İşletme Bölümü, Bilecik, Türkiye. meral.fidan@bilecik.edu.tr

\begin{tabular}{|c|c|}
\hline MAKALE BİLGİSİ & ÖZET \\
\hline Anahtar Kelimeler: & Amaç- Çalışmanın temel amacı BIST'de tekstil, giyim eşyası ve deri sektöründe işlem gör \\
\hline Finansal Başarısızlık & $\begin{array}{l}\text { letmelerin finansal başarısızlık riski taşıyıp taşımadıklarını Altman Z Skor modeli ve bağımsız } \\
\text { enetim raporlarında belirtilen kilit denetim konuları ile birlikte değerlendirmektir. }\end{array}$ \\
\hline Altman Z-Skor & Yöntem- Bağımsız denetim raporlarında kilit denetim konularının 2017 finansal raporlama dönemi \\
\hline Kilit Denetim & ile itibariyle başlamasından ötürü 2017 yılı finansal raporlardan başlayarak, 2018 ve 2019 dönemleri \\
\hline Borsa İstanbul & itibariyle BİST tekstil, giyim eşyası ve deri sektörüne giren 22 işletmenin finansal raporları \\
\hline Tekstil & leğerlendirme kapsamına alınmıştır. 2017-2019 yılları arasında tekstil sektöründe faaliyet gösteren \\
\hline Gönderilme Tarihi 13 Kasım & $\begin{array}{l}\text { işletmelerin finansal başarısızlık risklerini belirlemek için Altman Z Skor modeliyle finansal oranları } \\
\text { hesaplanmış olup finansal başarısızlık risk düzeyleri ile kilit denetim konuları kıyaslanmıştır. }\end{array}$ \\
\hline 2020 & Bulgular- Çalışma sonucunda, Türkiye'de tekstil, giyim eşyası ve deri sektöründe faaliyet gösterer \\
\hline Revizyon Tarihi 1 Ağustos 2021 & 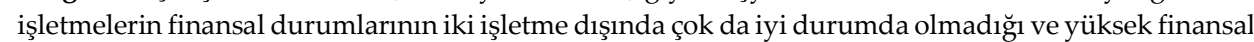 \\
\hline Kabul Tarihi 18 Ağustos 2021 & risk altında oldukları tespit edilmiştir. \\
\hline & $\begin{array}{l}\text { Tartışma- Günümüzde işletmeler zaman zaman finansal açıdan sıkıntılı dönemler geçirebilmektedir. } \\
\text { Finansal başarısızlığı bulunan her șirket kısa sürede iflas edecek denilemez fakat finansal açıdan kötü }\end{array}$ \\
\hline Makale Kategorisi: & durumda olan pek çok şirketin iflas etme ihtimali bulunmaktadır. Bu durum işletmelerin finansal \\
\hline Araştırma Makalesi & $\begin{array}{l}\text { başarısızlıklarını tahmine dayalı çalışmalar üzerinde yoğunlaşma gerekliliğini doğurmaktadır. } \\
\text { Altman'ın (1968) geliştirdiği Z-skor modeli işletmelerin finansal başarısızlığını ölçülmede yaygın } \\
\text { olarak kullanılan bir modeldir. }\end{array}$ \\
\hline
\end{tabular}

\begin{tabular}{ll}
\hline ARTICLE INFO & ABSTRACT \\
\hline Keywords: & $\begin{array}{l}\text { Purpose -This study aims to determine whether businesses traded in textile, clothing and leather } \\
\text { sectors on BIST have a risk of financial failure via Altman Z-Score model and key audit matters } \\
\text { specified in independent audit reports } \\
\text { Financial Failure }\end{array}$ \\
$\begin{array}{l}\text { Altman Z Score } \\
\text { Key Audit }\end{array}$ & $\begin{array}{l}\text { reports beginning from 2017 financial reporting period. The study, therefore, covers the evaluations } \\
\text { of financial reports of 22 businesses in textile, clothing and leather sectors on BIST for the years 2017- } \\
\text { İstanbul Stok Market } \\
\text { Textile }\end{array}$ \\
$\begin{array}{l}\text { 2019. Financial ratios were calculated with the Altman Z Score model in order to determine the } \\
\text { financial failure risks of companies in textile, clothing and leather industries between 2017-2019 and }\end{array}$ \\
Received 14 February 2021 \\
$\begin{array}{l}\text { the financial failure risk levels and key audit matters were compared. } \\
\text { Accepted 3 September 2021 }\end{array}$ \\
$\begin{array}{l}\text { Findings - It was concluded that the businesses in the study -apart from two of them- in textile, } \\
\text { clothing and leather sectors in Turkey are not in a very good financial state and they are at high } \\
\text { financial risk. } \\
\text { Discussion - Companies may go through financially troubled times now and then. Not every } \\
\text { company with financial failure is bound to go bankrupt in a short time, however many companies in } \\
\text { bad financial condition have such a possibility. That is why focusing on studies based on predictive } \\
\text { financial failures of businesses has become necessary. Z-Score model developed by Altman (1968) is } \\
\text { a widely used model to measure the financial failure of businesses. }\end{array}$
\end{tabular}




\section{GİRISS}

Ülkelerde zaman zaman çeşitli etkenlerle ortaya çıkan konjoktürel dalgalanmalar işletmeler için finansal risk ve finansal başarısızlık kavramlarını gündeme getirmektedir. Bir işletmenin finansal açıdan sıkıntıya düşmesi işletmenin tüm paydaşlarına etki etmektedir.

İşletmelerin faaliyetlerini sürdürmekteki asıl amaçları ortaklarının refahlarını maksimum düzeye çıkarmak ve piyasa değerini artırmaktır. Bunu gerçekleştiremediklerinde rakipleri karşısında piyasada ayak duramayacak, performansları olumsuz etkilenecek ve belki de faaliyetlerine son vermek durumunda kalacaklardır (KılıçSeyrek, 2012:678). İşletmelerin finansal başarısızlıklarında artış yaşanması genel anlamda ekonomik olarak durgunluk, enflasyonu önlemek adına uygulamaya sokulan sıkı para ve faiz politikaları, işletmelerin sahip olduğu kendi riskli finansal yapıları ile bağlantılıdır. İşletmelerde finansal başarısızlığın arttığı dönemlerde ülkede ekonomik resesyonların arttığı, para ve faiz üzerinde tedbirler uygulandığı ve bununla birlikte daha fazla yeni işletmelerin ortaya çıktığı da görülmektedir (Giray-Altaş, 2005: 14).

İşletmelerin finansal raporları işletmelerin geleceğinin yorumlanmasında önemli bilgiler vermektedir. İşletme raporlarının analizleri sonucunda finansal başarısızlık ihtimalleri önceden tahmin edilebilir ve olumsuz sonuçlar için gerekli tedbirler alınabilir. Finansal başarısızlığın ölçülmesine yönelik tahmin modellerinin başında Altman Z-skor analizi gelmektedir. Finansal başarısızlık kavramı finans literatürü içerisine 1960'lı yıllarda girmiştir. Sonrasında özellikle 1970'li yıllarda yaşanan ekonomik kriz dönemlerinde modelin önemi artmıştır (Akkaya vd. 2009: 189).

Altman halka açık imalat sektörü işletmelerinin iflas etme riskini tahmin etmeye çalıştı̆̆ bu model ile işletmelerin iflas etme olasılığını bir yıl öncesi dönemden yaklaşık \%90 oranında, iki yıl öncesi dönemden ise yaklaşık \%82 oranında başarılı bir şekilde tahmin edebildiğini belirtmiştir. Fakat yapılan çalışmalarda özel İşletmeler için bu modelin beklendiği gibi başarılı sonuçlar vermediği yönünde eleştiriler aldığını görmüştür. $\mathrm{Bu}$ sebeple Altman hazırladığı modelin üzerinde değişiklikler yaparak iki farklı model daha geliştirmiştir. Oluşturduğu Z' modelini özel imalat şirketleri için, $Z^{\prime \prime}$ modelini de hizmet işletmeleri için oluşturmuştur (Altman, 2000:14).

Türkiye ekonomisi içinde önemli sektörlerden bir tanesi olan tekstil, hazır giyim ve deri sektöründe karşılaşılan en önemli sorunların başında sektör şirketlerinin finansal yapılarının zayıf olması gelmektedir. Tekstil sektörü ülkede yaşanan finansal dalgalanmalardan önemli düzeylerde etkilenebilmektedir. Altman Z skor ile yapılmış olan çalışmalara bakıldığında Türkiye'de özellikle tekstil sektörünü baz alan çok fazla çalışmanın olmadığı görülmektedir. Bunun sebebi olarak finansal başarısızlık tahmin modellerinden biri olan Altman Z skor modeli sonucuna gerek olmadan Türk tekstil işletmelerinin finansal durumunun tahmin edilebilir olması düşünülebilir. Finansal başarısızlık tahmini ile ilgili yapılan araştırmalarda Altman Z Skor modeli farklı modellerle ve farklı değişkenlerle birlikte uygulanmakla birlikte, bağımsız denetim raporları kilit denetim konuları ile birlikte Altman Z skor modelinin birlikte uygulandığı sektör değerlendirmesinin yapılmamış olduğu görülmektedir.

Yapılan literatür incelemesinde özellikle gelişmekte olan ülkelerde Altman modeli ve bu modele benzeyen finansal tahmin modellerinin farklı sektör grupları için sürekli olarak yapıldığı ve genel olarak modelden olumlu yönde sonuçlar elde edildiği görülmektedir. Türkiye'de yapılmış olan araştırmalara bakıldığında Altman modelinin ve benzer modellerle ilgili araştırmaların özellikle 2010 yılı sonrası daha fazla yapılmaya başlandığı ve incelenen sektörle ilgili finansal başarısızlık tahmini üzerine yapılmış çalışmanın yok denecek kadar az olduğu görülmektedir.

Hazır Giyim sektörünün 2017 ve 2018 yıllarında sektörel bazda en çok ihracat yapan sektörler içerisinde 2. sırada yer aldığı görülmektedir (TíM, (2020: 29), (2019: 12)). Tekstil, Deri İmalatı ve Hazır Giyim sektörünün ihracat rakamlarına bakıldığında ise 2017 ve 2018 yıllarında \% 18'lerin üzerinde, 2019 yılında ise yaklaşık \% 17 oranda olduğu görülmektedir. (TiM, 2021).

2017 yılı Sosyal Güvenlik Kurumu (SGK) verilerine bakıldığında Türkiye' de sigortalı çalışan 14.477.817 içinde tekstil imalatında faaliyet gösteren 16.843 işletmede 422.166 kişinin, hazır giyim imalatında 33.071 işletmede 493.952 kişinin, deri ürünleri imalatında 6.451 işletmede 61.750 kişinin istihdam edildiği bilgisi yer almaktadır (T.C. Bilim, Sanayi ve Teknoloji Bakanlığı, 2018: 19). 2018 yılı SGK verilerine bakıldığında Türkiye'de sigortalı çalışan 14.229.170 kişi içinde tekstil imalatında faaliyet gösteren 16.904 işletmede 413.041 kişinin, hazır giyim 


\section{Erol Fidan 13/3 (2021) 1945-1969}

imalatında faaliyet gösteren 33.491 işletmede 525.146 kişinin, deri ürünleri imalatında faaliyet gösteren 6.344 işletmede ise 59.128 kişinin istihdam edildiği bilgisi yer almaktadır (T.C. Sanayi ve Teknoloji Bakanlığı, 2019: 21). Bu sektörde faaliyet gösteren işletmelerin finansal yapılarında ortaya çıkabilecek bozulmalar özellikle sektörün istihdamdaki önemi nedeniyle ülkenin ekonomisini olumsuz yönde etkileyecektir. Bu nedenle ülke ekonomisinde önemli etkilere sahip olan işletmelerin iflas risklerinin periyodik olarak analiz edilmesi ve ortaya çıabilecek olumsuz durumların erken tespit edilmesi sağlanmalıdır. Bu tip analizlerin düzenli olarak yapılması ile işletmelere ve paydaşlarına referans olacağı düşünülmektedir.

Çalışmanın temel amacı BIST'de Tekstil, Hazır Giyim ve Deri sektöründe işlem gören işletmelerin finansal başarısızlık riski taşıyıp taşımadıklarını Altman Z Skor modeli ile hesaplayarak, işletmelerin bağımsız denetim raporlarında belirtilen kilit denetim konuları ve bağımsız denetim raporlarında geçen denetçi görüşleri ile birlikte kıyaslayarak değerlendirmektir. Çalışma kapsamında yapılan literatür araştırmasında Altman Z Skor ile yapılmış olan çalışmalarda genellikle Altman Z Skor ile birlikte benzer bir modelin kıyaslanması ya da finansal rasyolarla kıyaslamalar yapıldığı görülmektedir. Bağımsız denetim raporları verileri ile birlikte Altman Z Skor sonuçlarının birlikte değerlendirildiği çalışmanın olmadığı görülmektedir.

\section{KAVRAMSAL ÇERÇEVE}

Çalışma kapsamında öncelikle Tekstil, Giyim Eşyası ve Deri Sektörü kapsamında yapılmış finansal başarı/başarısızlık konulu yerli ve yabancı çalışmalar incelenmiştir. Ayrıca Altman Z skor modeliyle test edilmiş diğer sektörler üzerinde yapılmış çalışmalar da değerlendirilerek, yapılmış çalışmaların kapsamı ve sonuçları hakkında Tablo 1'de kısa bilgiler verilmiştir.

Tablo 1: Konu İle İlgili Literatür

\begin{tabular}{|c|c|c|c|}
\hline Yazarlar & $\begin{array}{l}\text { Yayin } \\
\text { Tarihi }\end{array}$ & $\begin{array}{c}\text { İncelenen } \\
\text { Dönem }\end{array}$ & Yöntem, Kapsam ve Sonuç \\
\hline Kablan & 2020 & $2012-2017$ & $\begin{array}{l}\text { Türkiye'de faaliyet gösteren } 30 \text { büyükşehir belediyesi Altman modeli ile } \\
\text { değerlendirilerek risk haritası oluşturulmaya çalışılmıştır. Test } \\
\text { sonucunda ortalama skorlara göre } 2 \text { belediyenin kırmızı, } 1 \text { belediyenin } \\
\text { gri ve diğerlerinin güvenilir bölgede olduğu belirtilmiştir. }\end{array}$ \\
\hline $\begin{array}{l}\text { Gümüş ve } \\
\text { Altıok }\end{array}$ & 2020 & 2015-2019 & $\begin{array}{l}\text { Arçelik, Ford,Otosan, İskenderun Demir Çelik, Tofaş Türk Otomobil ve } \\
\text { Tüpraş incelenmiştir. Altman Z-Skor modeli, Springate Skor yöntemi ve } \\
\begin{array}{l}\text { Altman Z-Skor halka açık şirketler için uygulanan } 3 \text { yöntem } \\
\text { uygulanmıştır }\end{array}\end{array}$ \\
\hline Akyüz & 2020 & 2014-2018 & $\begin{array}{l}\text { Taş ve toprağa dayalı sektör işletmeleri üzerinde Altman Z Skor- } \\
\text { Springate ve Fulmer modelleri uygulanmıştır. Altman Z Score } \\
\text { yönteminin daha fazla kullanıldığ görülmekle birlikte, işletmelerin } \\
\text { finansal durumlarının tespitinde diğer yöntemlerden de } \\
\text { faydalanılmasını tavsiye etmektedir. }\end{array}$ \\
\hline $\begin{array}{l}\text { Bağcı ve } \\
\text { Sağlam }\end{array}$ & 2020 & 2014-2018 & $\begin{array}{l}4 \text { spor ve } 2 \text { sağlık işletmesi Altman, Springate ve Fulmer Modelleri ile } \\
\text { değerlendirilmiştir. Yapılan analiz sonucunda sağlık işletmelerinin iflas } \\
\text { riskiyle karşılaşma ihtimallerinin oldukça düşük olduğu fakat spor } \\
\text { işletmelerinin yüksek seviyede finansal başarısızlık riski taşıdığı } \\
\text { belirtilmektedir. }\end{array}$ \\
\hline $\begin{array}{l}\text { Erni ve } \\
\text { Sofyan }\end{array}$ & 2020 & 2013-2018 & $\begin{array}{l}6 \text { Go Public işletmesi Altman Z Skor ve Springate's model ile } \\
\text { değerlendirilmiştir. Go Public şirketlerinin yıllık mali tabloları olası iflas } \\
\text { göstermediği ve modellerin birbirine yakın sonuçlar verdiği } \\
\text { belirtilmektedir. }\end{array}$ \\
\hline $\begin{array}{l}\text { Izquierdo } \\
\text { vd. }\end{array}$ & 2020 & 2004-2014 & $\begin{array}{l}404 \text { adet finansal sıkıntı yaşayan ve } 404 \text { adet sıkıntılı olmayan İspanyol } \\
\text { şirketi Altman Z skor ile değerlendirilmiştir. } 5 \text { lojistik regresyon modeli } \\
\text { oluşturulmuştur. Hepsi yüksek bir ayırt etme ve tahmin etme gücüne } \\
\text { sahip olduğu belirtilmekle birlikte tahmini logit modellerinin } \\
\text { sinıflandırma doğruluğunun, geleneksel finansal oranlar modeline } \\
\text { kıyasla muhasebe ve denetim verilerini birleştiren modellerle önemli } \\
\text { ölçüde arttı̆gnı belirtmektedirler. }\end{array}$ \\
\hline
\end{tabular}


M. Erol Fidan 13/3 (2021) 1945-1969

\begin{tabular}{|c|c|c|c|}
\hline Mu'arifin & 2020 & 2017-2019 & $\begin{array}{l}\begin{array}{l}\text { Endonezya'da } 3 \text { tekstil ve hazır giyim işletmesi Altman Z skor ile } \\
\text { değerlendirilmiştir.3 işletmenin de finansal sıkıntıda olduğu } \\
\text { belirtilmektedir. }\end{array} \\
\end{array}$ \\
\hline $\begin{array}{l}\text { Rakshit ve } \\
\text { Paul }\end{array}$ & 2020 & 2010-2019 & $\begin{array}{l}\text { Hindistan'da } 30 \text { Tekstil firması Altman } Z \text { skor ile değerlendirilmiştir. } \\
\text { Mali açıdan sıkıntılı firmaların bile geliri azaltan kazanç yönetimi } \\
\text { uygulamaları yürüttüğünü, firmaların karlılık, likidite ve büyüme } \\
\text { fırsatlarının kazanç yönetimi üzerinde önemli bir pozitif etkiye sahip } \\
\text { olduğunu, Nakit Akışı Kapsamı (CFC) ve kaldıraç oranının ise kazanç } \\
\text { yönetimi ile önemli bir negatif ilişkiye sahip olduğu belirtilmektedir. }\end{array}$ \\
\hline Aksu & 2019 & 2009-2012 & $\begin{array}{l}\text { Altman Z" skor ve Springate S skor modelleri ile } 8 \text { enerji sektörü } \\
\text { işletmeleri değerlendirilmiştir. Enerji şirketlerinde finansal sıkınt1 } \\
\text { üzerinde finansal kaldıraç oranının etkisinin negatif, likiditenin ve aktif } \\
\text { karlıllğının etkisinin pozitif olduğu sonucuna ulaşılmıştır }\end{array}$ \\
\hline $\begin{array}{l}\text { Öztürk ve } \\
\text { Yilmaz }\end{array}$ & 2019 & 2016-2017 & $\begin{array}{l}\text { BİST Gelişen İşletmeler Piyasası'nda faaliyet gösteren } 17 \text { işletme } \\
\text { kapsamında Altman Z skor ve Beneish M skor modelleri ile } \\
\text { değerlendirmiştir. Finansal başarısızlık ve muhasebe manipülasyonu } \\
\text { arasında istatistiki olarak güçlü bir bağ olduğu belirtilmektedir. }\end{array}$ \\
\hline $\begin{array}{l}\text { Tuna ve } \\
\text { Aytekin }\end{array}$ & 2019 & 2015-2018 & $\begin{array}{l}\text { BIST'te Sürdürülebilirlik Endeksindeki } 41 \text { işletme Altman } Z \text {, Ohlson } O \text {, } \\
\text { Springate } S \text { ve Grover ile değerlendirilmiştir. Sabit etkiler modelinde } \\
\text { hisse senetlerinin getirisini Altman Z, Ohlson O ve Grover modelleri } \\
\text { değişkenleri olumsuz yönde etkilerken Springate değişkeninin olumlu } \\
\text { yönde etkilediği belirtilmiştir. Sabit etkiler modelinde hisse senetlerinin } \\
\text { kapanış fiyatlarını Altman Z ve Ohlson O değişkenleri olumsuz olarak } \\
\text { etkilediği belirtilmektedir. }\end{array}$ \\
\hline $\begin{array}{l}\text { Karadeniz } \\
\text { ve Öcek }\end{array}$ & 2018 & 2009-2018 & $\begin{array}{l}\text { Altman Z Skor, Springate, Fulmer, Kanada Skor ve Ohlson O-Skor } \\
\text { modelleriyle Thomas Cook şirketinin } 5 \text { yıllık finansal verileri } \\
\text { değerlendirilmiştir. Thomas Cook şirketinin tüm tahmin modellerine } \\
\text { göre finansal başarısızlık riski taşıdığ belirlenmiştir. Analizde kullanılan } \\
\text { tüm tahmin modellerinin şirketin iflasını } 2019 \text { yılından önceki yıllarda } \\
\% 100 \text { olarak doğru tahmin ettiği belirtilmektedir. }\end{array}$ \\
\hline $\begin{array}{l}\text { Apan, Öztel } \\
\text { ve İslamoğlu }\end{array}$ & 2018 & 2008-2014 & $\begin{array}{l}\text { Gıda ve İçecek sektöründe } 18 \text { işletmede Altman Z Skor ve VIKOR } \\
\text { yöntemi ile değerlendirilmiştir. Bu çalışmada, finansal başarısızlık } \\
\text { analizi için alternatif bir yöntem olarak VIKOR yöntemi önerilmiştir. }\end{array}$ \\
\hline $\begin{array}{l}\text { İslamoğlu ve } \\
\text { Çankaya }\end{array}$ & 2018 & 2012-2016 & $\begin{array}{l}\text { BIST Elektrik Endeksinde işlem gören } 6 \text { şirket Altman Z Skor, Fiyat- } \\
\text { Kazanç oranı, Fulmer H skor ve Tobin's Q oranı ile test edilmiştir. Tobin's } \\
\text { Q oranı, Fulmer H skor ve Fiyat-Kazanç oranlarının arasında pozitif } \\
\text { yönde bir ilişki tespit edilmiştir. Satışların logaritması ile negatif yönde } \\
\text { bir ilişki olduğu belirtilmektedir. }\end{array}$ \\
\hline Çelik & 2018 & 2015-2017 & $\begin{array}{l}\text { BİST-30 Endeksinde faaliyet gösteren imalat işletmeleri Altman Z Skor } \\
\text { modeli ile analiz edilmiştir. İki işletmenin incelenen dönemdeki yıllarda } \\
\text { Z-skor sonucunun alt sınır değerin altında olduğu ve sıkıntılı olarak } \\
\text { belirlenen diğer kalan şirketlerin güvenli olarak tespit edildiği } \\
\text { belirtilmektedir. }\end{array}$ \\
\hline Çalış vd. & 2018 & 2012-2017 & $\begin{array}{l}10 \text { konaklama işletmesi Altman Z skor ve finansal oranlar ile } \\
\text { değerlendirilmiştir. Turizm sektöründe kriz dönemi olarak } \\
\text { nitelendirilebilecek dönemde işletmelerin finansal durumunun dikkat } \\
\text { çekecek oranda olumsuz yönde değişmediği belirtilmiştir. }\end{array}$ \\
\hline Rozzy & 2018 & 2014-2016 & $\begin{array}{l}\text { Endonezya'da } 13 \text { tekstil ve hazır giyim işletmesi Ohlson Modeli (Y-Skor) } \\
\text { ve Altman (Z-Skor) ile değerlendirilmiştir. Altman modeli ile } 11 \text { firma ve } \\
2 \text { firma sağlıklı kategoride yer aldığı, Ohlson modelinde iflas tahmininde } \\
\text { bulunan } 4 \text { firma ve sağlıklı durumda kategorize edilmiş } 9 \text { firma } \\
\text { bulunduğu belirtilmektedir. }\end{array}$ \\
\hline
\end{tabular}




\begin{tabular}{|c|c|c|c|}
\hline Gör & 2018 & 2009-2016 & $\begin{array}{l}\text { Bist } 100 \text { endeksinde yer alan şirketler Altman Z skor ile } \\
\text { değerlendirilmiştir. Yapılan lojistik regresyon analizi neticesinde } \\
\text { kurumsal yönetim endeksinde yer alan Şirketlerin finansal açıdan } \\
\text { başarılı oldukları anlaşılmıştır. }\end{array}$ \\
\hline $\begin{array}{l}\text { Turaboğlu, } \\
\text { Erkol, ve } \\
\text { Topaloğlu }\end{array}$ & 2017 & $\begin{array}{l}2010- \\
2015\end{array}$ & $\begin{array}{l}\text { BIST100 endeksinde işlem gören } 37 \text { reel sektör firmasına Altman Z skor } \\
\text { ve Springate S-Skor modeli uygulanmıştır. Borçlanma oranının } \\
\text { işletmelerin finansal başarısızlığını arttırdığı yönünde sonuçlara ve } \\
\text { denge teorisin destekleyen sonuçlara ulaşıldığı belirtilmektedir. }\end{array}$ \\
\hline Gümüş vd. & 2017 & 2011-2015 & $\begin{array}{l}\text { BIST'te işlem gören çimento sektörü işletmeleri (Ford Otosan, Tofaş Türk } \\
\text { Otomobil, İskenderun Demir Çelik, Arçelik ve Tüpraş) incelenmiştir. } \\
2015 \text { yılında Afyon Çimento'nun; } 2012 \text { yılında ise Çimsa'nın iflas olasılığ } 1 \\
\text { olduğu belirtilmektedir. }\end{array}$ \\
\hline Akyüz vd. & 2017 & 2015 & $\begin{array}{l}\text { BIST'te kâğıt ve kâğıt ürünleri sanayi sektör işletmelerinden } 23 \text { tanesi } \\
\text { Altman Z-skor ve finansal oranlarla değerlendirilmiştir. } 7 \text { finansal } \\
\text { rasyonun kullanılabileceği ve modelin işletmelerin finansal başarısızlık } \\
\text { ölçümünde etkin olduğu belirtilmektedir. }\end{array}$ \\
\hline $\begin{array}{l}\text { Türk ve } \\
\text { Kürklü }\end{array}$ & 2017 & 2014-2016 & $\begin{array}{l}\text { BIST'e kayıtlı } 166 \text { adet şirket Altman (Z-Score) ve Springate (S-Score) ile } \\
\text { değerlendirilmiş. Altman modelinin \%69, Springate modelinin \%57 } \\
\text { oranda işletmelerin finansal anlamda sıkıntı içerisinde olmadığ1 } \\
\text { araştırma sonunda belirtilmiştir. }\end{array}$ \\
\hline $\begin{array}{l}\text { Ko, Fujita ve } \\
\mathrm{Li}\end{array}$ & 2017 & 2009-2014 & $\begin{array}{l}\text { Enerji sektöründe } 48 \text { işletme Altman Z skor modeliyle } \\
\text { değerlendirilmiştir. Sonuçların finansal analiz için başarılı bir şekilde bir } \\
\text { temel oluşturduğu ve Tayvan'ın güneş enerjisi endüstrisindeki sıkıntılı } \\
\text { şirketlerin kâr verimliliğinin düşmekte olduğu belirtilmiştir. }\end{array}$ \\
\hline $\begin{array}{l}\text { Husin ve } \\
\text { Yakob }\end{array}$ & 2017 & 2012-2014 & $\begin{array}{l}\text { Malezya'da } 12 \text { katılım sigorta işletmesi üzerinde Altman Z Skor analizi } \\
\text { yapılmıştır. Sigorta işletmesinin alarm durumunda olduğu ve modelin } \\
\text { en iyi sigorta işletmesi tespitinde kullanılabileceği belirtilmektedir. }\end{array}$ \\
\hline Kulalı & 2016 & $2000-2013$ & $\begin{array}{l}\text { BIST'te işlem gördüğü sürede iflasını açıklamış olan on dokuz işletmenin } \\
\text { finansal raporları Altman modeli ile test edilmiştir. Altman Z-Skor } \\
\text { modelinin finansal başarısızlık tahmin gücünün yüksek olduğu } \\
\text { belirtilmektedir. }\end{array}$ \\
\hline $\begin{array}{l}\text { Toraman ve } \\
\text { Karaca }\end{array}$ & 2016 & 2010-2013 & $\begin{array}{l}\text { BİST'te kimya sektöründe işlem gören on yedi işletme Altman Z skor ile } \\
\text { analiz edilmiştir. Toplam varlıklar içinde net çalışma sermayesinin, } \\
\text { stokların ve toplam borçların pay artışlarının işletmelerin finansal } \\
\text { başarıları üzerinde önemli etkiye sahip olduğu belirtilmektedir. }\end{array}$ \\
\hline $\begin{array}{l}\text { Soba, Akyüz } \\
\text { ve Uğurcan }\end{array}$ & 2016 & 2011-2015 & $\begin{array}{l}\text { BİST te işlem gören dokuz büyük işletme Altman Z skor modeliyle } \\
\text { değerlendirilmiştir. 2011- } 2015 \text { yılları arasında Altman yöntemine göre } \\
\text { analiz edilen risk düzeyi en az olan, borç karşılamasında iflas etme } \\
\text { olasıllı̆g az olan işletmenin BIMAS ve } 2015 \text { yılı dışında TKNSA } \\
\text { işletmesinin olduğu belirtilmektedir. }\end{array}$ \\
\hline $\begin{array}{l}\text { Koç ve } \\
\text { Ulucan }\end{array}$ & 2016 & 2006-2013 & $\begin{array}{l}13 \text { Tekstil ve } 13 \text { Teknoloji işletmeleri Altman Z skor yöntemiyle } \\
\text { değerlendirilmiştir. Altman Z Skoru sonucunda Teknoloji Endeksi } \\
\text { şirketlerinin Tekstil Endeksine göre daha başarılı olduğu } \\
\text { belirtilmektedir. Ayrıca Altman Z Skoru değerlerinin ANFIS yöntemi ile } \\
\text { birlikte değerlendirildiğinde önceden tespiti için olumsuz olası } \\
\text { gelişmelere karşı önlem almada kullanılabileceği belirtilmektedir. }\end{array}$ \\
\hline $\begin{array}{l}\text { Almamy, } \\
\text { Aston ve } \\
\text { Ngwa }\end{array}$ & 2016 & $2000-2013$ & $\begin{array}{l}\text { İngiltere'de } 1000 \text { başarılı işletme ve } 90 \text { başarısız üzerinde J-UK modeli ve } \\
\text { Altman Z skor modeli uygulanmıştır. J-UK adı verilen bir modeli } \\
\text { geliştirilerek Altman Z skor modeli ile birlikte karşılaştırıldığında } \\
\text { İngiltere'de J-UK modelinin finansal başarısızlık tahmininin daha yüksek } \\
\text { olduğu tespit edilmiştir. }\end{array}$ \\
\hline $\begin{array}{l}\text { Yasser ve } \\
\text { Mamun }\end{array}$ & 2015 & 2006-2010 & $\begin{array}{l}\text { Altman Z skor kullanılarak sektördeki } 25 \text { işletme değerlendirilmiştir. } \\
\text { Endüstriyel ulaşım ve endüstri mühendisliği sektörleri genel olarak }\end{array}$ \\
\hline
\end{tabular}




\begin{tabular}{|c|c|c|c|}
\hline & & & $\begin{array}{l}\text { güvenli bölge olarak sınıflandırılırken, gıda ve zımba perakendeciliği, } \\
\text { gayrimenkul yatırım ve hizmetleri ile endüstriyel metaller ve madencilik } \\
\text { sektörleri tehlike bölgesi olarak sınıflandırılır. }\end{array}$ \\
\hline Bağcl & 2015 & 2008-2013 & $\begin{array}{l}\text { Tekstil ve hazır giyim sektöründe } 24 \text { işletme Altman'ın Z-Skor modeli ve } \\
\text { finansal oranları uygulayarak finansal başarısızlı oranlarını } \\
\text { incelemiştir. İşletmelerin 2008-2013 dönemleri arası Z skor sonuçları } \\
\text { ortalama 0,62 olarak hesaplanmıştır. }\end{array}$ \\
\hline $\begin{array}{l}\text { Yilmaz ve } \\
\text { Yildıran }\end{array}$ & 2015 & 2001-2006 & $\begin{array}{l}\text { BİST'te işlem görmüş iflas eden } 18 \text { ve başarılı } 18 \text { işletme Altman Z Skor } \\
\text { ve finansal oranlarla birlikte değerlendirilmiştir. Altman Z-Skor } \\
\text { sonuçlarının \% } 89 \text { oranda on sekiz başarılı işletmeden on altısında, \% } 71 \\
\text { oranda, on dört başarısız olan işletmenin on tanesinde doğru şekilde } \\
\text { tahmin ettiği belirtilmektedir. }\end{array}$ \\
\hline Shahwan & 2015 & 2008 & $\begin{array}{l}\text { Mısırda } 86 \text { endüstri sektör işletmesi Tobin's Q ve Altman Modeli ile test } \\
\text { edilmiştir. KY uygulamaları ile finansal sıkıntı olasılığı arasında önemsiz } \\
\text { bir negatif ilişki vardır. Firmaya özgü özelliklerin, firma performansını } \\
\text { ve finansal sıkıntı olasılığını belirlemede ilk geçiş taraması olarak faydalı } \\
\text { olabileceği belirtilmektedir. }\end{array}$ \\
\hline $\begin{array}{l}\text { Selimoğlu } \\
\text { ve Orhan }\end{array}$ & 2015 & 2013-2014 & $\begin{array}{l}\text { BİST te } 25 \text { tekstil işletmesi Altman } \mathrm{Z} \text { skor ve Finansal Oranlarla test } \\
\text { edilmiştir. Yedi finansal rasyonun gruplar arasında istatistiki olarak } \\
\text { anlamlı farklılık gösterdiği belirlenmiştir. Bu yedi rasyoyu kullanarak } \\
\text { test edilen diskriminant analizi sonucunda, modelin yaklaşık \%92 } \\
\text { oranda başarılı olduğu tespit edilmiştir. }\end{array}$ \\
\hline Rim ve Roy & 2014 & 2009-2011 & $\begin{array}{l}\text { Lübnan imalat sektörü üzerinde }(10 \text { işletme }) \text { Altman Modeli test } \\
\text { edilmiştir. Bankaların ve yatırımcıların farklı şirketleri karşılaştırmak } \\
\text { için bir değerleme aracı olarak } Z \text { skoru güvenle kullanabileceği } \\
\text { belirtilmektedir. }\end{array}$ \\
\hline Yild1z & 2014 & $2010-2013$ & $\begin{array}{l}\text { Altman Z skor modeli ve kurumsal yönetim endeksi ile BIST 100'de yer } \\
\text { alan } 35 \text { firma değerlendirilmiştir. İşletmelerin yatırım yapma durumları } \\
\text { ile Altman Z skorları arasında istatistiki anlamlı bir ilişkiyi belirlemiştir. } \\
\text { Kurumsal yönetim endeksi ile yatırım yapma durumları arasında } \\
\text { istatistiki anlamlı bir ilişki bulunamadığı belirtilmektedir. }\end{array}$ \\
\hline $\begin{array}{l}\text { Büyükarıkan } \\
\text { ve } \\
\text { Büyükarıkan }\end{array}$ & 2014 & 2008-2013 & $\begin{array}{l}\text { BİST'te Bilişim Sektöründe işlem gören işletmeler Altman Z-Skor ve } \\
\text { Springate yöntemleri ile test edilmiştir. Her iki modelin de işletmelerin } \\
\text { finansal başarısılıklarının tespitinde birbirine yakın sonuçlar ortaya } \\
\text { çıkardığı belirtilmektedir. }\end{array}$ \\
\hline Bozkurt & 2014 & 2002-2012 & $\begin{array}{l}\text { Bist'te işlem gören } 168 \text { işletme Altman, Ohlson ve Springate modelleri ile } \\
\text { değerlendirilmiştir. İflas ihtimalinin yüksek olmasının sistematik riski } \\
\text { artırdığı ve Altman-Z, Ohlson-O ve Springate-S modellerinin BİST } \\
\text { işletmeleri risk tespiti için etkin olan model olduğu belirtilmektedir. }\end{array}$ \\
\hline Özdemir & 2014 & 2009-2011 & $\begin{array}{l}\text { Halka açı olan ve olmayan işletmeler Altman Z Skor ile test edilmiştir. } \\
\text { Halka açı seksen, halka açık olmayan da altmış iki tane imalat işletmesi } \\
\text { test edilmiştir. Halka açlk işletmeler yönüyle Z Skor modellerinin } \\
\text { tamamında işletmelerin gerçek finansal durumunu tahmin etmedeki } \\
\text { genel başarısının yüksek olduğu belirtilmektedir. }\end{array}$ \\
\hline $\begin{array}{l}\text { Civan ve } \\
\text { Dayı }\end{array}$ & 2014 & 2008-2012 & $\begin{array}{l}\text { Zonguldak Kamu Hastaneleri Birliği'ne bağlı olan sağlı işletmeleri } \\
\text { üzerinde Altman Z skor ve Yapay Sinir Ağı modeli test edilmiştir. En } \\
\text { başarılı yapay sinir ağları modeli, Altman Z Modelinin sonuçlarının, } \\
\text { yapay sinir ağı regresyon modelinde kullanılarak iflas tahmini yapıldığ1 } \\
\text { model olduğu belirtilmiştir. }\end{array}$ \\
\hline Hussain, vd. & 2014 & $2000-2010$ & $\begin{array}{l}\text { Pakistan'da } 21 \text { tekstil işletmesi Altman Z skor ile değerlendirilmiştir. } \\
\text { Pakistan tekstil sektörü için model İflas etmiş ve etmemiş işletmelerde } \\
\text { Altman modelinin iyi tahminler verebileceğini belirtilmektedir. }\end{array}$ \\
\hline
\end{tabular}




\begin{tabular}{|c|c|c|c|}
\hline Kartikasari & 2014 & 2008-2012 & $\begin{array}{l}\text { Endonezya'da } 8 \text { tekstil işletmesi Altman Z Skor modeli ile } \\
\text { değerlendirilmiştir. Ifflas olasılığı olan } 7 \text {, başarıll } 1 \text { işletme tespit edildiği } \\
\text { belirtilmiştir. }\end{array}$ \\
\hline $\begin{array}{l}\text { Alareeni ve } \\
\text { Branson }\end{array}$ & 2013 & 1989-2008 & $\begin{array}{l}\text { Ürdün'de İmalat ve endüstri sektöründen } 71 \text { başarılı } 71 \text { başarısız işletme } \\
\text { üzerinde Altman modeli test edilmiştir. Orijinal Altman Z-Score } \\
\text { modelinin etkili bir şekilde çalıştığı fakat hizmet şirketleri için, Altman } \\
\text { modellerinin başarısız olan ve olmayan şirketleri ayırt etmek için güçlü } \\
\text { göstergeler sağlayamadığı belirtilmektedir. }\end{array}$ \\
\hline Malik vd. & 2013 & 2006-2011 & $\begin{array}{l}\text { Karaçi Borsası'nda finans sektörü dışında olan otuz dört işletme Altman } \\
\text { modeliyle değerlendirilmiştir. İşletmelerin finansal sıkıntı durumları ile } \\
\text { hisse getirileri arasında pozitif yönde anlamsız ilişki olduğu ve iflas riski } \\
\text { olasılığının sistematik risk olup olmadığının da kesin olmadığı } \\
\text { belirtilmektedir. }\end{array}$ \\
\hline $\begin{array}{l}\text { Tokat, Çetin } \\
\text { ve } \\
\text { Karabulut }\end{array}$ & 2012 & 2004-2010 & $\begin{array}{l}\text { BİST'te teknoloji, ulaştırma, haberleşme ve depolama alanlarında işlem } \\
\text { gören işletmeler test edilmiştir. Altman Z-Skor modelinin işletme portföy } \\
\text { verimliliği yönüyle etkili olan bir unsur olmadığı belirtilmektedir. } \\
\text { İşletmelerin artan finansal risk düzeylerinin hisse senedi } \\
\text { performanslarını etkilemeyeceği belirtilmektedir. }\end{array}$ \\
\hline$Y i$ & 2012 & 2008-2009 & $\begin{array}{l}\text { Çin'in borsaya kote olan } 40 \text { gayrimenkul şirketi Z-skor modeli ile } \\
\text { değerlendirilmiştir. Modelin doğruluk oranını } \% 90 \text { olarak belirlemiştir. }\end{array}$ \\
\hline Terzi & 2011 & $2009-2010$ & $\begin{array}{l}\text { BIST Gıda sektöründe } 22 \text { işletme üzerinde Altman modeli ile birlikte } \\
\text { finansal başarısızlık modeli geliştirilmeye çalışılmıştır. İşletmelerin } \\
\text { finansal olarak başarılı olup olmadıklarının incelenmesi amacıyla } 19 \text { adet } \\
\text { rasyo belirlenmiştir. Modelde kullanılacak } 6 \text { rasyo belirlenmiştir. } \\
\text { Geliştirilen modelde yaklaşık \%91 oranda doğruluk oranı olduğu tespit } \\
\text { edilmiştir. }\end{array}$ \\
\hline $\begin{array}{l}\text { Hermavan, } \\
\text { Tirok ve } \\
\text { Dawis }\end{array}$ & 2011 & 2006-2008 & $\begin{array}{l}\text { Endonezya Borsasında işlem gören } 189 \text { işletme Altman Z skor ile } \\
\text { değerlendirilmiştir. Çok fazla şirketin gri bölgede yer aldığı ve güvenli } \\
\text { bölge şirketleri arasında Madencilik Endüstrisi ve en düşük derecede ise } \\
\text { Altyapı Endüstrisi olduğu belirtilmektedir. }\end{array}$ \\
\hline $\begin{array}{l}\text { Hayes, } \\
\text { Hodge ve } \\
\text { Hughes }\end{array}$ & 2010 & 2007-2008 & $\begin{array}{l}\text { Çalışmada } 9 \text { perakende sektörü işletmesi üzerinde Altman Z skor analizi } \\
\text { yapılmıştır. İki şirket hariç tüm şirketlerin iflaslarını (yüzde 94) oranda } \\
\text { doğru bir şekilde tahmin edilebilirliği belirtilmektedir. }\end{array}$ \\
\hline Gritta vd. & 2008 & 1995-1999 & $\begin{array}{l}\text { Altman Z Skor ile ABD büyük havayolu şirketleri (16 firma) ABD'de } \\
\text { Southwest firması haricinde firmaların, Altman Z skor modeli ile } \\
\text { ölçüldüğ̈ünde mali durumlarında düşüş yaşadığı tespit edilmiştir. }\end{array}$ \\
\hline $\begin{array}{l}\text { Poyraz ve } \\
\text { Uçma }\end{array}$ & 2006 & 1992-2003 & $\begin{array}{l}\text { Tekstil, tarımsal ürünler, gıda, turizm ve lojistik araçlarında faaliyet } \\
\text { gösteren işletmelerin yaşanan } 1994 \text { ve } 2001 \text { kriz dönemlerindeki finansal } \\
\text { başarısızlı durumları incelenmiştir. Her sektör incelenmiş ve } \\
\text { Türkiye'de ana ihracatçı sektör işletmelerin ilgili finansal krizlerinden } \\
\text { çok büyük olumsuzluklar yaşayarak çıktığını Altman modeli } \\
\text { yardımıyla yapılan analiz sonucunda söylenemeyeceği belirtilmektedir. }\end{array}$ \\
\hline
\end{tabular}

\section{ALTMAN Z SKOR MODELI}

Model 1968 yılında Edward Altman tarafından geliştirilmiştir. Altman iflas durumundaki 33 ve başarılı 33 firmayı incelemiş, mali tablolarından faydalanarak iflas tahminine 1şık tutan modeli gerçekleştirmiştir. Altman, finansal oranlara yapılan olumsuz eleştirilerin oranların yetersiz olmasından çok bu oranların tek tek hesaplanarak değerlendirilmesinden kaynaklanan çelişkili sonuçlardan kaynaklandığını belirtmektedir. Oranların tek tek ele alınması yerine aralarındaki etkileşimlerinin de göz önüne alınarak birleştirilmesi gerekliliğini öne sürmüştür (Altman, 1968: 589).

Altman modeli bir işletmenin iflas riski olasılığını tespit edebilmek amacıyla beş adet oranın arasındaki ilişkisi çoklu diskriminant analizi yardımıyla hesaplanmakta ve ağırlıklarına göre bulunarak bileştirilmiş bir orandan meydana gelmektedir (Arsoy; 1993: 160). Altman'ın oluşturduğu modelde Amerikan İflas Kanunu 
kapsamında iflas etmiş olan otuz üç adet işletme tespit edilmiştir. Varlık değerleri 1 milyon ABD Doları'nın altında olan işletmeler çalışmasına dahil edilmemiştir. İncelenen altmış altı işletmenin tamamı imalat işletmeleri arasından seçilmiştir (Meeampol vd., 2014:1229). Muhasebe temelli altı adet ve piyasa-temelli olarak bir adet olarak toplam yedi temel değer üzerinde Z-Skor modeli oluşturulmuştur. Belirlenen yedi adet temel değer ise oluşturulan beş adet oranın içerisinde yer almaktadır. Her bir oran, işletmelerin farklı kredi görünümleri hakkında bilgi verebildiği için Altman'ın oluşturduğu bu model akademide ilgiyle karşılanmış ve uygulanmıştır (Kulalı, 2016: 286):

Formül şu şekildedir: $Z=1,2 X 1+1,4 X 2+3,3 X 3+0.06 X 4+0.999 X 5$

Formülün anlamları aşağıdaki gibidir. Ayrıca Tablo 2'de kamuya açık imalat işletmeleri için Altman tarafından geliştirilen modelde elde edilecek skor değerlerinin hangi anlamlara geldiğini gösteren bölgeler belirtilmektedir.

X1: Çalışma sermayesi /Toplam Varlıklar

Çalışma sermayesi= Dönen Varlıklar- Kısa Vadeli Yabancı Kaynaklar

X2: Geçmiş yıl karı / Toplam Varlıklar

X3: Esas Faaliyet kar-zarar / Toplam Varlıklar

X4: Toplam Piyasa Değeri / Toplam Yükümlülükler: Özkaynak Defter Değeri/ Toplam Yükümlülükler

X5: Hasılat / Toplam Varlık

Tablo 2: Kamuya Açık Olan İmalat İşletmeleri İçin Z Skor Bölgeleri

\begin{tabular}{|c|l|}
\hline Z Skor Değeri & Yorumu \\
\hline$\ldots .<\mathrm{Z}<1,8$ & İflas etme ihtimali olan -Sıkıntılı (Kırmızı Bölge) \\
\hline $1,8<\mathrm{Z}<2,99$ & Belirsiz (Gri Bölge) \\
\hline $2,99<\mathrm{Z}<\ldots$ & Güvenli Risksiz Bölge ( Yeşil Bölge) \\
\hline
\end{tabular}

İşletmelerin borçlarını geri ödemede sorun yaşayıp yaşamayacağını veya finansal alanlarda sıkıntılarla karşılaşıp karşılayamayacağını önceden öngörebilmek amaçlarıyla farklı yöntemler geliştirilmeye çalışılmıştır. Altman tarafından geliştirilen Z skoru modeli uygulamada başarılı sonuçlar veren, uygulanması ve anlaşılması kolay, işletmeler tarafından hazırlanan ve bağımsız denetimden geçen raporlarda yer alan değerlerden elde edilen finansal bilgilere dayalı olarak güvenilir ve hızlı bir şekilde uygulanabilir bir modeldir. Altman Z skor modeli işletmelerin olası iflas durumlarını öngörmeye yönelik olarak geliştirilmesine rağmen, işletmelerin finansal performanslarını değerlendirme ve kredi sağlayanlar ile borç verenlerin yatırım kararlarını vermelerine yardımcı olabilecek bir yaklaşım olarak da kabul edilmektedir (Hauschild, 2013).

Altman geliştirdiği modelde kamuya açık olan imalat firmalarının iflas riskini tahmin etmeye çalışmıştır. Ancak yapılan akademik çalışmalarda özel firmalar üzerinde yapılan analizlerde Z Skor modelinin başarılı tahminler vermediği şeklinde eleştiriler alan Altman, modelinin üzerinde çalışmalar yaparak farklı sektörler için kullanılmak üzere iki farklı model daha geliştirmiştir. Altman, $Z^{\prime}$ modeli olarak bilinen modelini özel imalat sektörü firmaları için, $Z^{\prime \prime}$ modeli ise imalat sektöründe faaliyet göstermeyen firmalar ve hizmet sektöründe faaliyet gösteren firmalar için geliştirmiş olup formülleri aşağıdaki gibidir (Yıldız, 2014: 77):

$Z^{\prime}$ skor $=0.717 \mathrm{X} 1+0.847 \mathrm{X} 2+3.107 \mathrm{X} 3+0.42 \mathrm{X} 4+0.998 \mathrm{X} 5$

$Z^{\prime \prime}$ skor $=6.56 \mathrm{X} 1+3.26 \mathrm{X} 2+6.72 \mathrm{X} 3+1.05 \mathrm{X} 4$

\section{BAĞIMSIZ DENETIM RAPORLARINDA GÖRÜŞ TÜRLERİ VE KİİT DENETIM KONULARI}

Bağımsız Denetim Standardı (BDS 705) “Bağımsız Denetçi Raporunda Olumlu Görüş Dışında Bir Görüş Verilmesi" ile ilgili olup, işletmelerin finansal tabloları incelemesi sonucunda "olumlu görüş" dışında başka bir görüş verilmesi gerektiği durumları, bu raporların şekil ve içeriğini kapsamaktadır.

Finansal raporların önemli yanlışlık içerdiği veya yeterli sayıda ve uygun denetim kanıtlarının toplanamadığı durumlarda, finansal raporların önemli yanlışlık içerebileceği ve bu durumun işletmelerin finansal raporları 
üzerinde olabilecek etkilerin yaygınlığı ile ilgili olarak bağımsız denetçilerin yargılarının gerektiği durumlarda "olumlu görüş" dışında diğer görüşlere uygun olandan birini verebilmektedir.

BDS 705'e göre raporda" olumlu görüş" dışında verilebilecek olası görüş türleri şöyle belirtmektedir (BDS 705, 2017: 4):

1) Sınırlı olumlu görüş (şartlı görüş),

2) Olumsuz görüş,

3) Görüş vermekten kaçınma.

Denetçi, denetim süresince yeterli ve uygun denetim kanıtı elde etmiş olup; önemli yanlışlıkların tek veya toplu olarak önemli olduğu fakat finansal tablolarda yaygın olmadığı sonucuna varırsa sınırlı olumlu görüş verebilmektedir. Ayrıca denetim görüşüne dayanak teşkil edecek yeterli ve uygun denetim kanıtı elde edememekle birlikte eğer varsa tespit edilmemiş olan yanlışlıkların muhtemel etkilerinin finansal tablolar üzerinde önemli olabilmekle birlikte yaygın olmayabileceği sonucuna da varırsa yine sınırlı olumlu görüş verebilmektedir. Denetçi, denetim süresince yeterli ve uygun denetim kanıtı elde etmiş olup; yanlışlıkların tek veya toplu olarak finansal tablolar için önemli ve etkisinin yaygın olduğu kanaatine varırsa olumsuz görüş verebilmektedir. Denetçinin, görüşüne dayanak olacak yeterli ve uygun denetim kanıtı elde edemediği durumda ve eğer varsa tespit edemediği yanlışlıkların finansal tablolar üzerindeki olası etkisinin önemli ve yaygın olabileceği kanaatine varırsa, görüş vermekten kaçınılabileceği belirtilmektedir (BDS 705, 2017: 6).

Denetçinin olumlu görüş dışında bir görüş vermesine neden olan hususa ilişkin yaptığı muhakemenin ve söz konusu hususun finansal tablolar üzerindeki etkilerinin veya muhtemel etkilerinin yaygınlığının, verilecek görüş türünü nasıl etkilediğini göstermektedir. Denetçinin olumlu görüş vermenin dışında verebileceği görüş türlerini nasıl belirlemesi gerektiği BDS 705'te Tablo 3'te görüldüğü gibi tarif edilmiştir ( BDS 705, 2017:12).

Tablo 3: Olumlu Görüş Dışındaki Görüş Türleri Nasıl Belirlenir?

\begin{tabular}{|l|l|l|}
\hline $\begin{array}{l}\text { Olumlu Görüş Dışında Bir Görüş̧ } \\
\text { Verilmesine Neden Olan Husus }\end{array}$ & $\begin{array}{l}\text { Bu Hususun Finansal Tablolar Üzerindeki Etkisinin Yaygınlığı ve } \\
\text { Denetçi Muhakemesi Karşısındaki Durumu }\end{array}$ \\
\cline { 2 - 3 } & Önemli Ancak Yaygın Değilse & Önemli ve Yaygınsa \\
\hline $\begin{array}{l}\text { Finansal tabloların önemli } \\
\text { yanlışlık içermesi. }\end{array}$ & Sınırlı Olumlu Görüş (Şartlı) & Olumsuz Görüşs \\
\hline $\begin{array}{l}\text { Uygun ve yeterli sayıda denetim } \\
\text { kanıtı toplanamaması }\end{array}$ & Sınırlı Olumlu Görüş (Şartlı) & Görüş Vermekten Kaçınma \\
\hline
\end{tabular}

Kaynak: (BDS 705, 2017:12).

Geçmiş yıllarda işletmelerde yaşanan finansal skandallar ve dünyada yaşanan finansal krizler işletme denetimlerinin kalitesinin ve ihtiyaca uygun yapılıp yapılmadığının sorgulanmasına neden olmuştur. Uluslararası Denetim ve Güvence Standartları Kurulu (IAASB) bağımsız denetçiler tarafından hazırlanan raporların içeriğinin revize edilmesi ve genişletilmesinin, denetim mesleğinin işletmeler için önemli bir durum olduğunu kabul etmektedir. Kurul denetçi raporlarının paydaşlarla iletişim anlamındaki öneminin ve artması ve daha anlaşılabilir olması amacıyla Denetçi Raporu Projesi'ni 2011 yılında başlatmıştır. Bu proje kapsamında, uluslararası denetim standartlarında yapılan revizasyonlar 2015 tarihinde yürürlüğe alınmıştır (Yanık ve Karataş, 2017: 3).

Günümüz piyasalarında finansal raporlama uygulamalarının daha komplike ve karmaşık olması, subjektif kararlar içermesi gereken alanların daha fazla olması ve raporların çok daha fazla nitel bilgiler içermesi denetim raporlarının da revize edilmesi gereğini doğurmuştur. Artık finansal bilgi kullanıcıları daha fazla özetlenmiş, standartlaştırılmış ve daha anlaşılır bilgilere daha güvenilir bir şekilde ulaşmak istemektedirler (Çağıran -Varıcı, 2019: 195).

BDS 701 Kilit Denetim Konularının Bağımsız Denetçi Raporunda Bildirilmesi Standardı, 1/1/2017 tarihinde ve sonrasında başlayacak hesap dönemlerinin denetiminde uygulanmak üzere 09/03/2017 tarihli ve 30002 sayılı Resmi Gazete'de Türkiye Denetim Standartları Tebliği No: 46 ile yayımlanarak uygulamaya geçilmiştir (Resmi Gazete, 2017: Sayı: 30002). Standardın amac1; hazırlanan denetçi raporlarında kilit denetim konularının bildirilmesine ilişkin denetçilerin sahip olması gereken sorumluluklarını düzenlemektir (BDS 701, 2017: 6). 
Denetçi, üst yönetimden sorumlu olanlara bildirilen konular arasından, denetimin yürütülmesi sırasında azami düzeyde dikkat etmesini gerektiren konuları belirler. Bunlar aşağıdaki gibi belirtilmektedir (BDS 701, 2017: 8):

a) “BDS 315 İşletme ve Çevresini Tanımak Suretiyle 'Önemli Yanlışlık' Risklerinin Belirlenmesi ve Değerlendirilmesi Standardı uyarınca "önemli yanlışlık" riski daha yüksek olarak değerlendirilen veya ciddi riskli olduğu belirlenen alanlar,"

b) "Yüksek tahmin belirsizliğine sahip olduğu belirlenen muhasebe tahminleri dâhil yönetimin önemli yargılarını içeren finansal tablo alanlarına ilişkin önemli denetçi yargıları,"

c) "Dönem içinde gerçekleşen önemli olay veya işlemlerin denetime olan etkileri."

\section{YÖNTEM}

\subsection{Araştırmanın Modeli}

Çalışmanın temel amacı Borsa İstanbul'da Tekstil, Giyim Eşyası ve Deri sektöründe işlem gören işletmelerin finansal performanslarını inceleyerek, sektörün olası bir ekonomik kriz karşısındaki durumlarının yorumlanmasıdır. Ayrıca bağımsız denetim raporlarında geçen kilit denetim konuları da incelenerek sektör işletmelerinin finansal başarı/başarısızlık düzeyi hakkında değerlendirme yapmaktır.

Altman tarafından geliştirilen Z-Skor modellerinin işletmelerin finansal başarı veya başarısızlıkları hakkında fikir elde edilmesinde en yaygın şekilde kullanılan model olduğu yapılan literatür taramasında görülmektedir. Çalışma kapsamında Altman (1968) tarafından geliştirilen ilk model test edilecektir. Çalışmada Altman modelinde elde edilen Z skorları ile birlikte işletmelerin bağımsız denetim raporları sonuçları ve raporda geçen kilit denetim konuları birlikte değerlendirilecektir. 2017 yılından itibaren kilit denetim konularının zorunlu olarak bağımsız denetim raporlarında belirtilmesi gerekliği nedeniyle incelenen dönemler 2017 yılı ve sonrası olarak değerlendirme kapsamına alınmıştır.

\subsection{Evren ve Örneklem}

Çalışmada BIST İmalat Sanayii Tekstil, Giyim Eşyası ve Deri Sektöründe faaliyet gösteren 22 işletmenin 20172018-2019 yıllarına ait finansal raporları ile bağımsız denetim raporları verileri değerlendirilmiştir. İncelenen işletmelerin KAP'te yayınlanan bağımsız denetim raporları içerik analizi ile değerlendirilerek, işletmelerin bağımsız denetçi görüşleri ve denetçilerin raporda belirttikleri kilit denetim konuları tespit edilmiştir. İşletmelerin dönemler itibariyle hesaplanan Altman Z skor değerleri ile birlikte kilit denetim konuları kıyaslanarak finansal başarı/başarısızlığa etki eden unsurlar belirlenmeye çalışılmıştır.

\subsection{Veri Seti}

Çalışma kapsamında kullanılacak verilerin elde edilmesinde öncelikle Kamu Aydınlatma Platformu (KAP)'te yayınlanan işletme verileri ve işletmelerin kendi web sitelerinden faydalanılmıştır.

\subsection{Verilerin Analizi}

Tekstil, Giyim Eşyası ve Deri sektöründe yer alan 22 işletmenin önce Z Skor değerleri 2017, 2018 ve 2019 yılları itibariyle hesaplanmıştır. Tablo 4, 5 ve 6'da üç yıl için hesaplanan oranlar ve $Z$ skor sonuçları verilmektedir.

Tablo 4: Tekstil, Giyim Eşyası ve Deri Sektör İşletmelerinin 2017 Dönemine Ait Oran ve Z Skor Sonuçları

\begin{tabular}{|l|c|c|c|c|c|c|}
\hline \multirow{2}{*}{ Firmalar } & \multicolumn{6}{c|}{$\mathbf{2 0 1 7}$} \\
\cline { 2 - 7 } & $\mathbf{Z}$ & $\mathbf{X 1}$ & $\mathbf{X 2}$ & $\mathbf{X 3}$ & $\mathbf{X 4}$ & $\mathbf{X 5}$ \\
\hline Ateks & 1,1817 & 0,04685 & 0,27023 & 0,03446 & 1,39063 & 0,38778 \\
\hline Arsan & 1,1468 & 0,03569 & 0,16141 & 0,06173 & 2,77016 & 0,50857 \\
\hline Blcyt & 1,6156 & 0,20132 & 0,07673 & 0,16643 & 2,45687 & 0,57163 \\
\hline Brko & $-0,8711$ & $-0,09486$ & $-0,68234$ & $-0,03387$ & 2,24978 & 0,017495 \\
\hline Brmen & $-0,8406$ & $-0,1316$ & $-0,63145$ & $-0,02745$ & 1,82036 & 0,18293 \\
\hline Bossa & 1,232 & $-0,00082$ & 0,12739 & 0,0894 & 1,12835 & 0,69257 \\
\hline Dagi & 1,3219 & 0,3861 & $-0,00676$ & 0,03781 & 2,90151 & 0,56973 \\
\hline
\end{tabular}


M. Erol Fidan 13/3 (2021) 1945-1969

\begin{tabular}{|l|c|c|c|c|c|c|} 
Derim & 1,4835 & 0,26808 & 0,08019 & 0,06791 & 1,15713 & 0,75678 \\
\hline Deras & Yok & & & & & \\
\hline Desa & 0,3642 & $-0,53898$ & $-0,05368$ & 0,05546 & 1,38259 & 0,82094 \\
\hline Dirit & $-0,4169$ & $-0,06594$ & $-0,47379$ & $-0,01589$ & 2,11858 & 0,25109 \\
\hline Hatek & 0,8797 & 0,01054 & 0,07263 & $-0,0009$ & 2,81861 & 0,59982 \\
\hline Krtek & 1,4068 & 0,04567 & $-0,14594$ & 0,20827 & 1,28186 & 0,79292 \\
\hline Kords & 1,693 & 0,09342 & 0,18146 & 0,09687 & 2,35237 & 0,86695 \\
\hline Luksk & 0,894 & 0,05997 & 0,15423 & 0,04628 & 2,26286 & 0,31799 \\
\hline Mndrs & 1,2871 & 0,07464 & 0,03621 & 0,10518 & 1,40724 & 0,71598 \\
\hline Rodrg & 0,8785 & 0,29649 & $-0,12882$ & $-0,01196$ & 1,72863 & 0,63944 \\
\hline Royal & 0,0544 & $-0,07436$ & 0,07196 & $-0,09147$ & 1,16856 & 0,27489 \\
\hline Sktas & 0,5659 & $-0,0564$ & $-0,1713$ & 0,07778 & 1,18751 & 0,54605 \\
\hline Snpam & 1,9441 & 0,13864 & 0,06185 & 0,06424 & 19,3635 & 0,3177 \\
\hline Yatas & 2,3784 & 0,10506 & 0,0365 & 0,18909 & 1,77036 & 1,47245 \\
\hline Yünsa & 1,7024 & 0,00517 & $-0,13234$ & 0,17766 & 1,36413 & 1,21452 \\
\hline
\end{tabular}

Tablo 5: Tekstil, Giyim Eşyası ve Deri Sektör İşletmelerinin 2018 Dönemine Ait Oran ve Z Skor Sonuçları

\begin{tabular}{|l|c|c|c|c|c|c|}
\hline \multirow{2}{*}{ Firmalar } & \multicolumn{5}{c|}{$\mathbf{2 0 1 8}$} \\
\cline { 2 - 7 } & $\mathbf{Z}$ & $\mathbf{X 1}$ & $\mathbf{X 2}$ & $\mathbf{X 3}$ & $\mathbf{X 4}$ & $\mathbf{X 5}$ \\
\hline Ateks & 1,3136 & 0,06652 & 0,2428 & 0,04327 & 3,22094 & 0,55839 \\
\hline Arsan & 1,1050 & 0,00478 & 0,23008 & 0,06839 & 2,51483 & 0,40096 \\
\hline Blcyt & 2,0310 & 0,23283 & 0,09957 & 0,24118 & 2,73350 & 0,65299 \\
\hline Brko & $-0,9609$ & $-0,06657$ & $-0,82041$ & $-0,02714$ & 2,79641 & 0,18958 \\
\hline Brmen & $-0,7169$ & $-0,40332$ & $-0,22818$ & $-0,01041$ & 1,48122 & 0,03208 \\
\hline Bossa & 1,5174 & 0,06123 & 0,05213 & 0,17848 & 1,21582 & 0,70972 \\
\hline Dagi & 1,4209 & 0,26253 & $-0,00962$ & 0,06077 & 2,47855 & 0,77085 \\
\hline Derim & 1,7226 & 0,32551 & 0,11978 & 0,08481 & 1,16460 & 0,81537 \\
\hline Deras & 3,2906 & 0,16283 & 0,04935 & 0,22415 & 1,42288 & 2,20328 \\
\hline Desa & 1,8178 & 0,12746 & $-0,04956$ & 0,12375 & 1,47815 & 1,24486 \\
\hline Dirit & $-1,4188$ & $-0,19544$ & $-0,60043$ & $-0,19934$ & 1,37047 & 0,22572 \\
\hline Hatek & 1,8948 & 0,05267 & 0,05888 & 0,06326 & 2,75818 & 0,64103 \\
\hline Krtek & 2,0376 & 0,08721 & $-0,11797$ & 0,3641 & 1,22518 & 0,82393 \\
\hline Kords & 1,5820 & 0,09623 & 0,12496 & 0,10878 & 1,93884 & 0,8171 \\
\hline Luksk & 1,7204 & 0,12725 & 0,35205 & 0,13563 & 2,11914 & 0,50061 \\
\hline Mndrs & 1,4056 & $-0,06038$ & 0,04572 & 0,07613 & 1,17505 & 1,09336 \\
\hline Rodrg & 0,9233 & 0,25154 & $-0,11612$ & 0,00985 & 1,67748 & 0,65155 \\
\hline Royal & 0,2929 & $-0,12114$ & $-0,05076$ & $-0,00127$ & 1,10724 & 0,44758 \\
\hline Sktas & 0,4810 & $-0,16251$ & $-0,183$ & 0,11613 & 1,19967 & 0,47753 \\
\hline Snpam & 0,8835 & 0,14088 & $-0,12218$ & 0,11199 & 2,66981 & 0,35615 \\
\hline Yatas & 2,1762 & 0,17282 & 0,00211 & 0,16267 & 1,75955 & 1,32485 \\
\hline Yünsa & 1,7600 & 0,08794 & $-0,05446$ & 0,15424 & 1,38902 & 1,1395 \\
\hline
\end{tabular}


M. Erol Fidan 13/3 (2021) 1945-1969

Tablo 6: Tekstil, Giyim Eşyası ve Deri Sektör İşletmelerinin 2019 Dönemine Ait Oran ve Z Skor Sonuçları

\begin{tabular}{|l|c|c|c|c|c|c|}
\hline \multirow{2}{*}{ Firmalar } & \multicolumn{6}{c|}{$\mathbf{2 0 1 9}$} \\
\cline { 2 - 7 } & $\mathbf{Z}$ & $\mathbf{X 1}$ & $\mathbf{X} \mathbf{2}$ & $\mathbf{X 3}$ & $\mathbf{X 4}$ & $\mathbf{X 5}$ \\
\hline Ateks & 1,6035 & 0,06652 & 0,2428 & 0,04327 & 2,81836 & 0,55839 \\
\hline Arsan & 1,1412 & 0,00478 & 0,23008 & 0,06839 & 2,00854 & 0,40096 \\
\hline Blcyt & 2,5507 & 0,23283 & 0,09957 & 0,24118 & 6,59468 & 0,65299 \\
\hline Brko & $-1,3734$ & $-0,06657$ & $-0,82041$ & $-0,02714$ & 2,52529 & 0,18958 \\
\hline Brmen & $-1,2622$ & $-0,40332$ & $-0,22818$ & $-0,01041$ & 1,42096 & 0,03208 \\
\hline Bossa & 1,4913 & 0,06123 & 0,05213 & 0,17848 & 1,33230 & 0,70972 \\
\hline Dagi & 1,0851 & 0,26253 & $-0,00962$ & 0,06077 & 1,95522 & 0,77085 \\
\hline Derim & 2,6521 & 0,32551 & 0,11978 & 0,08481 & 1,30414 & 0,81537 \\
\hline Deras & 2,8882 & 0,16283 & 0,04935 & 0,22415 & 2,26099 & 2,20328 \\
\hline Desa & 1,6852 & 0,12746 & $-0,04956$ & 0,12375 & 1,34024 & 1,24486 \\
\hline Dirit & $-3,3347$ & $-0,19544$ & $-0,60043$ & $-0,19934$ & 0,94387 & 0,22572 \\
\hline Hatek & 0,8328 & 0,05267 & 0,05888 & 0,06326 & 3,58565 & 0,64103 \\
\hline Krtek & 1,4555 & 0,08721 & $-0,11797$ & 0,3641 & 1,20640 & 0,82393 \\
\hline Kords & 1,3266 & 0,09623 & 0,12496 & 0,10878 & 1,64802 & 0,8171 \\
\hline Luksk & 1,7167 & 0,12725 & 0,35205 & 0,13563 & 2,09912 & 0,50061 \\
\hline Mndrs & 1,1421 & $-0,06038$ & 0,04572 & 0,07613 & 1,13419 & 1,09336 \\
\hline Rodrg & 1,4399 & 0,25154 & $-0,11612$ & 0,00985 & 1,75029 & 0,65155 \\
\hline Royal & 0,2346 & $-0,12114$ & $-0,05076$ & $-0,00127$ & 0,96191 & 0,44758 \\
\hline Sktas & 0,6415 & $-0,16251$ & $-0,183$ & 0,11613 & 3,44841 & 0,47753 \\
\hline Snpam & 0,1245 & 0,14088 & $-0,12218$ & 0,11199 & 1,11905 & 0,35615 \\
\hline Yatas & 2,1397 & 0,17282 & 0,00211 & 0,16267 & 1,71531 & 1,32485 \\
\hline Yünsa & 1,8142 & 0,08794 & $-0,05446$ & 0,15424 & 1,36994 & 1,1395 \\
\hline
\end{tabular}

Tablo 7: Tekstil, Giyim Eşyası ve Deri Sektör İşletmelerinin 2017-2019 Dönemlerine Ait Z Skorları ve Z Skor Bölgeleri

\begin{tabular}{|c|c|c|c|c|c|c|c|}
\hline & \multirow{2}{*}{ Firmalar } & \multicolumn{2}{|c|}{2017} & \multicolumn{2}{|c|}{2018} & \multicolumn{2}{|c|}{2019} \\
\hline & & $\mathrm{Z}$ & Bölge & $\mathrm{Z}$ & Bölge & $\mathbf{Z}$ & Bölge \\
\hline 1 & Ateks & 1,1817 & Sikıntılı & 1,3136 & Sikıntılı & 1,6035 & Sıkıntılı \\
\hline 2 & Arsan & 1,1468 & Sikıntılı & 1,1050 & Sikıntılı & 1,1412 & Sikıntılı \\
\hline 3 & Blcyt & 1,6156 & Sikıntılı & 2,0310 & Belirsiz & 2,5507 & Belirsiz \\
\hline 4 & Brko & $-0,8711$ & Sikıntılı & $-0,9609$ & S1kıntılı & $-1,3734$ & Sikıntılı \\
\hline 5 & Brmen & $-0,8406$ & Sikıntılı & $-0,7169$ & S1kıntılı & $-1,2622$ & Sikıntılı \\
\hline 6 & Bossa & 1,2320 & Sikıntılı & 1,5174 & S1kıntılı & 1,4913 & Sikıntılı \\
\hline 7 & Dagi & 1,3219 & Sikıntılı & 1,4209 & S1kıntılı & 1,0851 & Sikıntılı \\
\hline 8 & Derim & 1,4835 & Sikıntılı & 1,7226 & S1kıntılı & 2,6521 & Belirsiz \\
\hline 9 & Deras & Yok & Yok & 3,2906 & Güvenli & 2,8882 & Belirsiz \\
\hline 10 & Desa & 0,3642 & Sikıntılı & 1,8178 & Belirsiz & 1,6852 & Sikıntılı \\
\hline 11 & Dirit & $-0,4169$ & Sikıntılı & $-1,4188$ & Sikıntılı & $-3,3347$ & Sıkıntılı \\
\hline 12 & Hatek & 0,8797 & Sikıntılı & 1,8948 & Belirsiz & 0,8328 & Sikıntıli \\
\hline
\end{tabular}


M. Erol Fidan 13/3 (2021) 1945-1969

\begin{tabular}{|c|c|c|c|c|c|c|c|}
\hline 13 & Krtek & 1,4068 & Sikıntılı & 2,0376 & Belirsiz & 1,4555 & Sikıntıli \\
\hline 14 & Kords & 1,6930 & Sikıntılı & 1,5820 & Sikıntılı & 1,3266 & Sikıntıl \\
\hline 15 & Luksk & 0,8940 & Sikıntılı & 1,7204 & Sikıntılı & 1,7167 & Sıkıntılı \\
\hline 16 & Mndrs & 1,2871 & Sikıntılı & 1,4056 & Sikıntılı & 1,1421 & Sikıntılı \\
\hline 17 & Rodrg & 0,8785 & S1kıntılı & 0,9233 & Sikıntılı & 1,4399 & Sikıntılı \\
\hline 18 & Royal & 0,0544 & Sikıntılı & 0,2929 & Sikıntılı & 0,2346 & Sikıntıli \\
\hline 19 & Sktas & 0,5659 & Sikıntılı & 0,4810 & Sikıntılı & 0,6415 & Sikıntıl \\
\hline 20 & Snpam & 1,9441 & Belirsiz & 0,8835 & Sikıntılı & 0,1245 & Sikıntıll \\
\hline 21 & Yatas & 2,3784 & Belirsiz & 2,1762 & Belirsiz & 2,1397 & Belirsiz \\
\hline 22 & Yünsa & 1,7024 & Sikıntılı & 1,7600 & Sikıntılı & 1,8142 & Belirsiz \\
\hline
\end{tabular}

Hesaplanan Z skor sonuçlarına göre işletmelerin Z skor bölgeleri tespit edilmiştir. İşletmelerin Z skor bölgeleri ise Tekstil, Giyim Eşyası ve Deri sektör işletmelerinin 2017,2018 ve 2019 yılları finansal raporlarından elde edilen verilerle hesaplanan Z Skor sonuçları ve Z Skor bölgeleri Altman Z skor modelinde belirtilen üç adet Z skor bölgesine göre Tablo 7' de verilmektedir. 2017 yılı için Tekstil, Giyim Eşyası ve Deri sektöründe yer alan 22 işletmeden on dokuzunun Z skor bölgesi sıkıntılı olarak tespit edilmiştir. Sadece iki işletme belirsiz bölgede olduğu tespit edilmiştir. 2018 yılı için on altı işletme sıkıntılı bölgede, beş işletme belirsiz bölgede ve bir işletme risksiz bölgede tespit edilmiştir. 2019 yılı için on yedi işletme sıkıntılı bölgede ve beş işletme ise belirsiz bölgede tespit edilmiştir. Üç yılda da sektör işletmelerinin çoğunluğunun Alman Z skor sonuçlarına göre finansal olarak başarısız oldukları görülmektedir.

Altman modeli sonuçlarına göre (Tablo 7) risksiz bölgede çıkan işletmelerin kilit denetim sayılarına ve bağımsız denetçi görüşlerine baktığımızda (Tablo 8); 2017 yılında iki işletmenin belirsiz bölgede olduğu ve bağımsız denetçi görüşlerinin olumlu olduğu görülmektedir. İki işletmede toplam iki tane kilit denetim konusu belirtildiği (Ek'lerde kilit denetim konularının başlıkları verilmektedir) görülmektedir. 2018 yılında ise bir işletmenin risksiz bölgede yer almakla birlikte şartlı bağımsız denetçi görüşü verildiği görülmüştür. Şartlı görüş alan bu işletmenin 2018 yılında BİST'te işlem görmeye yeni başladığı Tablo 7'de görülmektedir. 2018 yılında beş işletmenin ise belirsiz bölgede yer aldığı tespit edilmiştir. 2019 yılında incelenen 22 işletmenin tamamında risksiz bölgede çıkan işletme tespit edilmemekle birlikte beş işletmenin belirsiz bölgede çıktığı tespit edilmiştir. 2019 yılında belirsiz bölgede tespit edilen işletmelerin tamamının olumlu bağımsız denetim görüşü aldığı görülmektedir.

Tablo 8: Yıllara Göre Firmaların Bağımsız Denetim Raporlarında Geçen Denetçi Görüşleri ve Bağımsız Denetim Raporlarında Belirtilen Kilit Denetim Sayıları (2017-2019)

\begin{tabular}{|l|l|c|l|l|l|c|}
\hline Yıllar & \multicolumn{2}{|c|}{2017} & \multicolumn{2}{c|}{ 2018 } & \multicolumn{2}{c|}{2019} \\
\hline Firmalar & $\begin{array}{l}\text { Denetçi } \\
\text { Görüşü }\end{array}$ & $\begin{array}{c}\text { Kilit Denetim } \\
\text { Sayıs1 }\end{array}$ & $\begin{array}{l}\text { Denetçi } \\
\text { Görüşü }\end{array}$ & $\begin{array}{c}\text { Kilit Denetim } \\
\text { Sayıs1 }\end{array}$ & $\begin{array}{l}\text { Denetçi } \\
\text { Görüşü }\end{array}$ & $\begin{array}{c}\text { Kilit Denetim } \\
\text { Sayısı }\end{array}$ \\
\hline Ateks & Olumlu & 3 & Şartlı & 3 & Olumlu & 4 \\
\hline Arsan & Olumlu & 1 & Olumlu & 3 & Olumlu & 3 \\
\hline Blcyt & Olumlu & 1 & Olumlu & 2 & Olumlu & 1 \\
\hline Brko & Olumlu & 0 & Şartlı & 0 & Şartlı & 0 \\
\hline Brmen & Olumlu & 2 & Şartlı & 1 & Olumlu & 1 \\
\hline Bossa & Olumlu & 2 & Olumlu & 3 & Olumlu & 1 \\
\hline Dagi & Olumlu & 5 & Olumlu & 5 & Olumlu & 2 \\
\hline Derim & Olumlu & 1 & Olumlu & 1 & Olumlu & 1 \\
\hline Deras & Yok & Yok & Şartlı & 1 & Olumlu & 2 \\
\hline Desa & Şartlı & 2 & Şartlı & 4 & Şartlı & 3 \\
\hline Dirit & Şartlı & 2 & Şartlı & 1 & Olumlu & 0 \\
\hline Hatek & Olumlu & 2 & Olumlu & 1 & Olumlu & 1 \\
\hline
\end{tabular}


M. Erol Fidan 13/3 (2021) 1945-1969

\begin{tabular}{|l|l|l|l|l|l|c|} 
Krtek & Olumlu & 3 & Olumlu & 3 & Olumlu & 3 \\
\hline Kords & Olumlu & 1 & Olumlu & 2 & Olumlu & 2 \\
\hline Luksk & Olumlu & 2 & Şartlı & 1 & Şartlı & 1 \\
\hline Mndrs & Olumlu & 3 & Olumlu & 4 & Şartlı & 3 \\
\hline Rodrg & Olumlu & 2 & Olumlu & 2 & Olumlu & 2 \\
\hline Royal & $\begin{array}{l}\text { Görüş } \\
\text { Bildirmekten } \\
\text { Kaçınma }\end{array}$ & 1 & Olumlu & 1 & Olumsuz & 1 \\
\hline Sktas & Olumlu & 2 & Olumlu & 2 & Olumlu & 2 \\
\hline Snpam & Olumlu & 0 & Olumlu & 2 & Şartlı & 1 \\
\hline Yatas & Olumlu & 2 & Olumlu & 3 & Olumlu & 2 \\
\hline Yünsa & Olumlu & 1 & Olumlu & 1 & Olumlu & 1 \\
\hline
\end{tabular}

Tekstil, Giyim Eşyası ve Deri sektör işletmelerinin bağımsız denetim raporları incelendiğinde üç yılda da en fazla beyan edilen kilit denetim konusunun" hasılatın muhasebeleştirilmesi" konusu olduğu (bkz: Ekteki Tablolar) görülmektedir. Ayrıca "Yatırım Amaçlı Gayrimenkuller ve Maddi Duran Varlıkların Yeniden Değerlendirilmesi" ve "Ticari Alacaklar" konuları da raporlarda sayıca fazla olarak belirtilmektedir.

\section{SONUÇ VE TARTIŞMA}

Çalışmada 2017-2019 yılları arası BİST'te işlem gören Tekstil, Giyim Eşyası ve Deri Sektörü içerisinde yer alan 22 işletmenin finansal tabloları Altman Z Skor modeli ile değerlendirilmiş ve bağımsız denetim raporlarında geçen kilit denetim konuları ile denetçi görüşleri açısından kıyaslanmıştır. Altman Z Skor sonuçlarına bakıldığında her üç dönemde de işletmelerin çoğunluğunun finansal açıdan sıkıntılı bölgede oldukları tespit edilmiştir.

Altman modelinde $\mathrm{Z}$ değeri 1,81'in altında kalan işletmelerin bir ekonomik kriz yaşandığı takdirde iflas riskinin yüksek olasılıkta olduğunu belirtmektedir. Çalışma kapsamında incelenen işletmelerin 2017-2019 yılları arasında $Z$ değerlerinin çoğunluğunda 1,81'in altında kaldığı tespit edilmiştir. 2017' de iki, 2018 ve 2019 yıllarında ise beş işletmenin risksiz bölgede olduğu tespit edilmiştir. İncelenen dönem aralığında genel olarak işletmelerin düşük çalışma sermayesi ile çalıştıkları, kısa vadeli yabancı kaynaklarla borçlanma oranının yüksek olduğu, finansman giderleri öncesi faaliyet karlarının düşük olduğu söylenebilir.

İncelenen yirmi iki işletmenin bağımsız denetim raporları denetçi görüşleri ve kilit denetim konularına göre değerlendirildiğinde ise 2017 yılında iki işletmenin şartlı denetçi görüşü aldığı ve bir işletmenin görüş bildirmekten kaçınma şeklinde denetçi görüşü aldığı tespit edilmiştir. 2018 yılında ise yedi işletmenin şartlı görüş aldığı, on beş işletmenin olumlu görüş aldığı tespit edilmiştir. 2019 yılında ise beş işletmenin şartlı, on yedi işletmenin olumlu görüş aldığı görülmektedir. Bu verilere bakıldığında BİST'te Tekstil, Giyim Eşyası ve Deri sektöründe yer alan firmaların incelenen dönemlerde yaklaşık \% 10-\%30 kadarının şartlı denetçi görüşü aldığı söylenebilir. Kilit denetim konularına bakıldığında incelenen dönem aralığında sayı olarak en az sıfır en fazla beş adet kilit denetim konusunun raporlarda belirtildiği tespit edilmiştir. Sektörde faaliyet gösteren işletmelerin bağımsız denetim raporlarında belirtilen kilit denetim konu başlıklarına bakıldığında en fazla "Hasılatın Muhasebeleştirilmesi/Kaydedilmesi" kilit denetim konusu olduğu göze çarpmaktadır. Ayrıca "Maddi Duran Varlıklar ve Yatırım Amaçlı Gayrimenkullerin Yeniden Değerlendirilmesi" ve "Ticari Alacaklar" kilit denetim konu başlıkları da işletmelerin bağımsız denetim raporlarında sayıca diğer kilit denetim konularına kıyasla belirtilmiştir.

İşletmeler finansal olarak başarısız olma ihtimallerini her ne kadar bir yıl öncesinden tahmin edebilme imkanına sahip olsalar da özellikle iki yıl veya daha erken tahmin edebilmek için kullanılan finansal rasyolara ilave olarak başka değişkenlerin kullanılmasına da ihtiyaç olduğu söylenebilir. Yapılan analiz ve değerlendirmeler sonunda BİST'te işlem gören Tekstil Giyim Eşyası ve Deri sektöründe işlem gören işletmelerin finansal başarı durumlarının çok da iyi durumda olmadığı ve yüksek risk altında faaliyet göstermeye çalıştıkları söylenebilir. 


\section{Erol Fidan 13/3 (2021) 1945-1969}

Globalleşmeyle birlikte işletmelerin ulusal ve uluslararası piyasalarda faaliyet göstermeleri rakiplerinin ve müşterilerinin sayısının arttırmakta bu da işletmelerin finansal başarısını önemli ölçüde etkilemektedir. İşletmelerin yaşamlarını uzun süreli devam ettirebilmesi için de cari dönemleriyle birlikte ilerleyen yıllardaki dönemlerdeki finansal durumlarını iyi analiz etmesi gerekmektedir. Bu sebeple finansal başarı/başarısızlık tahminleri yapmak da işletmeler açısından hayati bir önem teşkil etmektedir. Son yıllarda finansal başarısızlık tahmini ile ilgili yapılan çalışmaların sayısındaki artış da bu konunun önemini göstermektedir.

İşletmelerin finansal başarısızlığı sadece işletme sahip ve ortakları ile ticari ilişkide olduğu kişi ya da işletmelerle sınırlı olmayıp, ekonomik anlamda ilişkili olduğu tasarruf sahipleri, iştirakleri, kredi kurumları, çalışanları, müşterileri ve ülke ekonomisi gibi her paydaşı yakından ilgilendirmektedir. Bu durum gerek işletme gerek ülke ekonomisi açısından gelecekteki finansal performansının önceden tahmin edilmesine yönelik olan çalışmaların önem kazanmasına neden olmaktadır.

Yapılan literatür çalışmasında özellikle yurt dışı çalışmalarda Altman Z skor başta olmak üzere birçok tahmin modellerinin son yıllarda akademisyenler tarafından borsalarında işlem gören bütün sektör grupları için sıklıkla uygulandığı ve sektörler hakkında ilgili grupları bilgilendirdikleri görülmektedir. Türkiye'de de son on yıl içinde finansal tahmin modellerinin kullanımının arttığı görülmekle birlikte, borsadaki bütün sektör gruplarının incelenmediği görülmektedir.

Çalışmada ele alınan dönemler itibariyle modelden elde edilen skor sonuçları ile işletmelerin bağımsız denetim raporlarında belirtilen denetim görüşleri ve kilit denetim konuları birlikte değerlendirilmek istenmiştir. Çalışmada incelenen sektörde faaliyet gösteren işletme sayısının çok az olması nedeniyle verimli bir değerlendirme olmamakla birlikte finansal başarısızlık tahmin modelleri ve denetçi raporlarının bir arada değerlendirilerek işletmelerle ilgili finansal durum değerlendirmesi yapılmasının daha faydalı olacağı bu çalışma ile belirtilmeye çalışılmıştır. İşletmelerin finansal başarılarını tespit etmede tahmin aracı olarak geliştirilen bu modeller ile işletmelerin bağımsız denetçiler tarafından incelenen finansal raporları sonrasında hazırladıkları denetçi görüş raporlarında yer alan unsurlar bir arada değerlendirilerek hem işletmeler hem de paydaşlar açısından daha sağlıklı finansal kararlar almaları sağlanabilir.

Çalışmada daha geniş bir sektörün incelenmesi ile kilit denetim konuları ile finansal başarısızlık tahmin modelleri bir arada değerlendirildiğinde istatistiksel olarak da analizler yapılabileceği ve daha anlamlı sonuçlar elde edilebileceği düşünülmektedir. Bağımsız denetçi raporlarında belirtilen her bir tespitin işletmelerin mevcut ve gelecekteki finansal durumları için birer gösterge olduğu ve farklı finansal modellerle birlikte değerlendirilebileceği düşünülmektedir.

Çalışmada Altman Z Skor Modeli uygulaması için belirlenen dönem kilit denetim konularının bağımsız denetim raporlarında geçmeye başladığı 2017 yılı itibariyle değerlendirmeye alınmıştır. Çalışmada BİST'te işlem göre Tekstil, Giyim Eşyası ve Deri sektör grubu işletmeleri değerlendirilmiş olup, diğer sektörler ya da endekslerde işlem gören işletmeler de Altman modeli veya diğer finansal başarısızlık tahmin modelleri ile değerlendirilebilir. Bu gibi çalışmaların sıklıkla yapılması işletmelerin ve sektörlerin finansal olarak mevcut ve gelecekteki risk durumlarını görebilme ve yatırımcların da yatırım kararını almalarını kolaylaştıracağı söylenebilir. 


\section{KAYNAKÇA}

Akkaya, G.C., Demireli, E. \& Yakut, Ü.H. (2009). İşletmelerde finansal başarısızlık tahminlemesi: Yapay sinir ağları modeli ile İMKB üzerine bir uygulama. Eskişehir Osmangazi Üniversitesi Sosyal Bilimler Dergisi, 10(2), 187-216.

Aksu, M. (2019). Türkiye'de enerji şirketlerinde finansal sıkıntının belirleyicileri. ICOAEF VI International Conference on Applied Economics and Finance Extended With Social Sciences. November 16-17, 2019, Burhaniye, Balıkesir.

Akyüz, F. (2020). Taş ve toprağa dayalı sektörde faaliyet gösteren şirketlerin finansal başarısızlık risklerinin tahmin edilmesi. Ömer Halisdemir Üniversitesi İktisadi ve İdari Bilimler Fakültesi Dergisi. Cilt-Sayı: 13(1) ss: $40-51$.

Akyüz, K.C. vd. (2017). Borsa İstanbul'da işlem gören kâğıt ve kâğıt ürünleri sanayi işletmelerinin finansal başarısızlık düzeylerinin oran analizi ve diskriminant analizi yöntemleri kullanılarak ölçülmesi. Journal of Forestry. 13(1): 60-74.

Alareeni B. \& Branson J. (2013). Predicting listed companies' failure in jordan using Altman models: a case study. International Journal of Business and Management. 8 (1): 113-126

Almamy, J., John, A. \& Ngwa, L.,N. (2016). An evaluation of Altman's Z-score using cash ratio to predict corporate failure amid the recent financial crisis: Evidence from the UK, Journal of Corporate Finance. 36: $278-285$.

Altman, E. (1968). Financial Ratios, Discriminant analysis and the prediction of corporate bankruptcy. The Journal of Finance. 23(4).

Altman, E.I. (2000). Predicting financial distress of companies: revisiting the z-score and zeta models. http://people.stern.nyu.edu/ealtman/Zscores.pdf, 10.02.2021.

Apan, M., Öztel, A. \& İslamoğlu, M. (2018). Comparative empirical analysis of financial failures of enterprises with altman z-score and VIKOR methods: BIST food sector application. Australasian Accounting, Business and Finance Journal AABFJ. 12 (1): 77-101.

Arsoy, A. (1993). İşletme sermayesi yönetimi, Gazi Büro Kitabevi, Ankara.

Bağc1, E. (2015). Türkiye tekstil ve hazır giyim sektörünün finansal durum analizi. Marmara Üniversitesi İ.İ.B. Dergisi. 37 (2): 83-100.

Bağcı, H. \& Sağlam, Ş. (2020). Sağlık ve spor kuruluşlarında finansal başarısızlık tahmini: Altman, Springate ve Fulmer modeli uygulaması. Hacettepe Sağlık İdaresi Dergisi, 23(1): 149-164.

BDS 701, (2017). Kilit denetim konularının bağımsız denetçi raporunda bildirilmesi, Türkiye Denetim Standartları.http://www.kgk.gov.tr/Portalv2Uploads/files/Duyurular/v2/BDS/bdsyeni25.12.2017/BD S\%20701-Site.pdf.

BDS 705, (2017). Bağımsız denetçi raporunda olumlu görüş dışında bir görüş verilmesi. Türkiye Denetim Standartları,https://kgk.gov.tr/Portalv2Uploads/files/Duyurular/v2/BDS/BDSyeni11092019/BDS_705. pdf.

Bozkurt, İ. (2014). İflas olasıllı̆̆ ile sistematik risk ilişkisinin incelenmesi ve etkin iflas göstergesi modellerinin tespiti: BİST'de ampirik bir uygulama. Süleyman Demirel Üniversitesi İktisadi ve İdari Bilimler Fakültesi Dergisi, 127-142.

Büyükarıkan, U. \& Büyükarıkan, B. (2014). Bilişim sektöründe faaliyet gösteren firmaların finansal başarısızlık tahmin modelleriyle incelenmesi. Akademik Bakış Dergisi. 46: 160-172.

Civan, M. \& Dayı, F. (2014). Altman Z skoru ve yapay sinir ağları modeli ile sağlık işletmelerinde finansal başarısızlık tahmini. Akademik Bakış Dergisi. 41. https://www.akademikbakis.org/file/41.pdf. 


\section{Erol Fidan 13/3 (2021) 1945-1969}

Çağıran (Kalıpçı) F. \& Varıcı, İ. (2019). Bağımsız denetim standardı (BDS) 701 çerçevesinde kilit denetim konuları: borsa İstanbul imalat sanayi sektöründeki işletmelerin denetim raporları üzerine bir analiz, Uluslararası İktisadi ve İdari İncelemeler Dergisi. 22, 193-208.

Çalış, Y. E vd. (2018). Borsa İstanbul'da faaliyet gösteren lokanta ve oteller sektörünün finansal durum ve performanslarının değerlendirilmesi. Uşak Üniversitesi Sosyal Bilimler Dergisi. XI, Aralık: 293-318.

Çelik, M. S. (2018). Altman Z skor modeli kullanılarak BIST -30 endeksinde yer alan imalat şirketlerinin finansal başarısızlık riskinin tahmin edilmesi. 5th International Congress on Political, Economic and Social Studies (ICPESS). ICPESS 2018 Proceedings Volume 2: Economic Studies. 26-29 October, Niğde/Turkey, 525-535.

Giray, S. \& Altaş, D. (2005). Mali başarısızlığın çok değişkenli istatistiksel yöntemlerle belirlenmesi: tekstil sektörü örneği. Sosyal Bilimler Dergisi. 13-25.

Gör, Y. (2018). Kurumsal yönetimin finansal başarısızlığı önlemedeki yeri üzerine bir araştırma. Avrasya Sosyal ve Ekonomi Araştırmaları Dergisi. 5 (12): 689-697.

Gritta R.D., vd. (2008). An update on airline financial condition and insolvency prospects using the Altman zscore model. Journal Transportation Research Forum. 47 (2): 133-138.

Gümüş Umut T. \& Altıok, Enes (2020). Borsa İstanbul'da işlem gören imalat sektöründeki firmalarının finansal başarısızlıklarının ölçülmesi. Türkiye Ekonomisi İşletme, İktisat ve Muhasebe Açısından Konjonkturel Değerlendirmeler. İksad Yayınevi. Ankara.

Gümüş, U.T. vd. (2017). BİST 100'de işlem gören çimento şirketlerinin finansal performanslarının Altman-Z skor yöntemiyle incelenmesi. International Journal of Academic. 3(12): 129-135.

Hauschild, D. (2013). Altman Z-Score: not just for bankruptcy: from z-score to "green zone" survivability, Amros Corporation.

Hayes, S.K., Hodge, K.A. \& Hughes, L.W. (2010). A study of the efficacy of Altman's Z to predict bankruptcy of specialty retail firms doing business in contemporary times. Economics \& Business Journal: Inquiries E Perspectives. 3(1) :122-135.

Hermawan, M. S., Tirok, J. \& Dawis, D. S. (2011). The degree of company vulnerability using Altman model: A survey of public listed companies in Indonesia. Journal of Applied Finance and Accounting. 2 (2). 8899.

Husin, N.H. \& Yakob, R. (2017). Aplikasi skor-Z Altman dalam menganggar kesolvenan pengendali takaful di Malaysia. Jurnal Pengurusan. 50:1-15.

Hussain, F. vd. (2014). Can Altman Z-score model predict business failures in pakistan? "evidence from textile companies of Pakistan. Journal of Economics and Sustainable Development. 5(13) : 110-115.

Izquierdo, N.M. vd. (2020). Does audit report information improve financial distress prediction over Altman's traditional Z-Score model?. Wiley J Int Financ Manage Account. 31:65-97.

İslamoğlu, M. \& Çankaya, S. (2018). Finansal başarının tahmininde finansal başarısızlık modellerinin kullanılması: BIST XELKT endeksine dahil firmalar üzerine bir uygulama. Maliye ve Finans Yazıları 2018 - (110). 111 - 134.

Kablan, A. (2020). Altman's Z"-score to predict accounting based financial distress of municipalities: bankruptcy risk map for metropolitan municipalities in Turkey. Işletme Araştırmaları Dergisi. 12(1): 498509.

Karadeniz, E. \& Öcek C. (2020). Finansal başarısızlık tahmin modellerinin geçerliliğinin analizi: Thomas Cook örneği. Seyahat ve Otel İ̧letmeciliği Dergisi. 17(3): 394-406.

Kartikasari, F.(2014). Prediksi kebangkrutan berdasarkan analisis z-score Altman (studi pada kelompok perusahaan textile and garment yang terdaftar di be1 selama Tahun 2008-2012). Jurnal Administrasi Bisnis. 9 (1) :1-10. 


\section{Erol Fidan 13/3 (2021) 1945-1969}

Kılıç, Y. \& Seyrek, İ. (2012). Finansal başarısızlık tahmininde yapay sinir ağlarının kullanılması: İmalat sektöründe bir uygulama, 1. International Symposium on Accounting and Finance, s. 1-15.

Koa, Y.C. Fujita, H. \& Li, T. (2016). An evidential analysis of Altman Z-score for financial predictions: case study on solar energy companies. Journal of Corporate Finance. 36: 278-285.

Kulalı, İ.(2016). Altman Z-skor modelinin BİST şirketlerinin finansal başarısızlık riskinin tahmin edilmesinde uygulanması. Uluslararası Yönetim İktisat ve İşletme Dergisi. 12(2): 283-291.

Malik, U.S., Aftab, M.\& Noreen, U. (2013). Distress risk and stock returns in an emerging market. Research Journal of Finance and Accounting. 4 (17): 81-85.

Meeampol, S., Lerskullawat P., \& Wongsorntham A. (2014). Applying emerging market Z-score model to predict bankruptcy: a case study of listed companies in the stock exchange of Thailand (Set). Management, Knowledge and Learning International Conference, 25 -27 June, Slovenia.

Mu'arifin, H. (2020). Analisis prediksi kebangkrutan dengan menggunakan metode Altman (z score) pada perusahaan textile dan garmen pada Tahun 2017-2019). Seminar Nasional Akuntansi (Sena) III. Universitas Pamulang Tahun: 436-441.

Özdemir, F.S. (2014). Halka açık ve halka açık olmayan işletmeler yönüyle tekdüzen muhasebe sistemi ve Altman z skor modellerinin uygulanabilirliği. Ege Akademik Bakış. 14 (1): 147-161.

Öztürk, S. \& Yılmaz, C. (2019). Finansal sıkıntının muhasebe manipülasyonu ile ilişkisi: BíST gelişen işletmeler piyasasında bir uygulama. Karadeniz Uluslararası Bilimsel Dergisi. 41: 241-254.

Poyraz E. \& Uçma T. (2006). Türkiye'de faaliyet gösteren ihracatçı sektörlerin mali kriz ortamlarında finansal başarısızlıklarının Altman (Z-Score) modeli yardımıyla ölçülmesi. Muhasebe ve Finansman Dergisi. Say1:32.

Prasetiyani, E. \& Sofyan, M.(2020). Bankruptcy analysis using Altman z-score model and Springate model in retail trading company listed in Indonesia stock exchange, Ilomata International Journal of Tax $\mathcal{E}$ Accounting. 1 (3) : 139-144.

Rakshit, D. \& Paul, A. (2020). Earnings management and financial distress: an analysis of Indian textile companies. Nmims Journal of Economics And Public Policy, 5 (3): 40-53.

Rim, E. K. \& Roy, A. B. (2014). Classifying manufacturing firms in Lebanon: An application of Altman's model. Procedia - Social and Behavioral Sciences. 109, 11-18.

Rozzy, N.S. (2018). Analisis prediksi kebangkrutan pada perusahaan dengan model Olson (y-score) dan Altman (z-score): (studi pada perusahaan textile and garment yang terdaftar di bursa efek indonesia periode 2014-2016). Jurnal Administrasi Bisnis. 55 (1): 161-169.

Selimoglu, S. \& Orhan, A. (2015). Finansal başarısızlığın oran analizi ve diskriminant analizi kullanılarak ölçümlenmesi: BIST'de işlem gören dokuma, giyim eşyası ve deri işletmeleri üzerine bir araştırma, Muhasebe ve Finansman Dergisi. 66: 21-40.

Shahwan, T. M. (2015). The effects of corporate governance on financial performance and financial distress: Evidence from Egypt. Corporate Governance, 15(5). 641-662.

Soba M., Akyüz F. \& Uğurcan Y. (2016). Şirketlerin finansal performanslarının Altman yöntemiyle analizi: Borsa İstanbul örneği., Uşak Üniversitesi Sosyal Bilimler Dergisi. 9(4): 65-87.

T.C. Sanayi ve Teknoloji Bakanlığı (2019), Tekstil, Hazırgiyim Ve Deri Ürünleri Sektörleri Raporu(2019): Sektörel Raporlar ve Analizler Serisi, https://www.sanayi.gov.tr/assets/pdf/planprogram/TekstilHaz\%C4\%B1rgiyimveDeri\%C3\%9Cr\%C3\%BCnleriSekt\%C3\%B6rleriRaporu(2019).p $\mathrm{df}$

T.C. Bilim, Sanayi ve Teknoloji Bakanlığı (2018), Tekstil, Hazırgiyim Ve Deri Ürünleri Sektörleri Raporu: Sektörel Raporlar ve Analizler Serisi, https://www.sanayi.gov.tr/assets/pdf/planprogram/TekstilHaz\%C4\%B1rgiyimveDeri\%C3\%9Cr\%C3\%BCnleriSekt\%C3\%B6rleriRaporu(2018).p $\mathrm{df}$ 
M. Erol Fidan 13/3 (2021) 1945-1969

Terzi, S. (2011). Finansal rasyolar yardımıyla finansal başarısızlık tahmini: gıda sektöründe ampirik bir araştırma, Çukurova Üniversitesi İiBF Dergisi, 15(1): 1-18.

Tokat, H.A., Çetin, Ş. \& Karabulut, M. (2012). İMKB'de sektörel olarak Altman z-skor yönteminin uygulanması ve yöntemin yatırımcı için kullanılabilirliğinin tartışılması. Finans Politik \& Ekonomik Yorumlar. 49 (574). 101-108.

Tuna, M. \& Aytekin S. (2019). İşletmelerin finansal başarısızlığının tahmin edilmesi: BIST'te bir uygulama. ICOAEF VI International Conference on Applied Economics and Finance ve Extended With Social Sciences November 16-17, 2019 / Burhaniye / Balıkesir.

Türk, Z. \& Kürklü, E. (2017). Financial failure estimate in BİST companies with altman (Z-score) and springate (S-score) models. Osmaniye Korkut Ata Üniversitesi İktisadi ve İdari Bilimler Fakültesi Dergisi. 1 (1): 1-14.

Türkiye İhracatçlar Meclisi (TIM), (2021). Sektörel Bazda İhracat Rakamları. https://tim.org.tr/tr/ihracatrakamlari

Türkiye İhracatçlar Meclisi (TIM), (2020), 2018-2019 Yillı Faaliyet Raporu. https://tim.org.tr/files/downloads/Raporlar/TIM_Faaliyet_Raporu_2018-2019.pdf

Türkiye İhracatçlar Meclisi (TIM), (2019), 2017-2018 Yıllık Faaliyet Raporu https://tim.org.tr/files/downloads/Raporlar/T\%C4\%B0M_2017_2018_Faaliyet_Raporu.pdf

Yanık, S. \& Karataş, M. (2017). Denetim raporlarının geleceği: yeni düzenlemeler ve ülke uygulamaları, Muhasebe ve Finansman Dergisi. 1-26.

Yasser Q. R. \& Mamun A. A. (2015). Corporate failure prediction of public listed companies in Malaysia. European Research. 91(2): 114-126.

Yıldız, A. (2014). Kurumsal yönetim endeksi ve Altman z skoruna dayalı lojistik regresyon yöntemiyle şirketlerin kredi derecelendirmesi, Süleyman Demirel Üniversitesi İktisadi ve İdari Bilimler Fakültesi Dergisi, 19 (3): 71-89.

Yılmaz, H. \& Yıldıran, M. (2015). Borsada işlem gören işletmelerde mali başarısızlık tahmini: altman modelinin BIST uygulaması. Aksaray Üniversitesi İktisadi ve İdari Bilimler Dergisi, 43-49.

Yi, W. (2012). Z-score model on financial crisisearly-warning of listed real estate companies in China: A financial engineering perspective. System Engineering Procedia. 3: 153-157. 
Ekler:

Tablo 9: 2019 Y1lı Kilit Denetim Konuları

\begin{tabular}{|c|c|c|c|c|c|}
\hline Firma & Görüş & 1 & 2 & 3 & 4 \\
\hline Ateks & Olumlu & $\begin{array}{l}\text { Ticari Alacakların Geri } \\
\text { Kazanılabilirliği }\end{array}$ & $\begin{array}{l}\text { Stok değer } \\
\text { düşüklüğü karş1llğg }\end{array}$ & $\begin{array}{l}\text { MDV yeniden } \\
\text { değerleme metodu ile } \\
\text { muhasebeleştirilmesi }\end{array}$ & $\begin{array}{l}\text { Yatırım Amaçlı } \\
\text { Gayrimenkullerin } \\
\text { Gerçeğe Uygun } \\
\text { Değerlerinin } \\
\text { Belirlenmesi }\end{array}$ \\
\hline Arsan & Olumlu & $\begin{array}{l}\text { Yatırım Amaçlı } \\
\text { Gayrimenkullerin } \\
\text { Gerçeğe Uygun } \\
\text { Değerlerinin } \\
\text { Belirlenmesi }\end{array}$ & $\begin{array}{l}\text { Yatırım Amaçlı } \\
\text { Gayrimenkullerin } \\
\text { Gerçeğe Uygun } \\
\text { Değerlerinin } \\
\text { Belirlenmesi }\end{array}$ & $\begin{array}{l}\text { MDV yeniden } \\
\text { değerleme }\end{array}$ & \\
\hline Blcyt & Olumlu & Hasılatın Kaydedilmesi & & & \\
\hline Brko & Şartlı & & & & \\
\hline Brmen & Olumlu & $\begin{array}{l}\text { Arazi ve arsalar ve } \\
\text { yatırım amaçlı } \\
\text { gayrimenkullerin } \\
\text { gerçeğe uygun değer } \\
\text { tespiti }\end{array}$ & & & \\
\hline Bossa & Olumlu & $\begin{array}{l}\text { Gerçeğe uygun değer } \\
\text { yöntemi ile } \\
\text { muhasebeleştirilen } \\
\text { yatırım amaçlı } \\
\text { gayrimenkuller ve } \\
\text { MDV }\end{array}$ & & & \\
\hline Dagi & Olumlu & $\begin{array}{l}\text { Hasılatın } \\
\text { Muhasebeleştirilmesi }\end{array}$ & $\begin{array}{l}\text { TFRS 16, Kiralamalar } \\
\text { Standardı'nın } \\
\text { uygulanması ve } \\
\text { finansal tablolar ve } \\
\text { finansal tablolara } \\
\text { ilişkin etkileri }\end{array}$ & & \\
\hline Derim & Olumlu & $\begin{array}{l}\text { Ticari alacakların geri } \\
\text { kazanılabilirliği }\end{array}$ & & & \\
\hline Deras & Olumlu & Stoklar ve değerlemesi & $\begin{array}{l}\text { Ticari alacakların } \\
\text { geri kazanılabilirliği }\end{array}$ & & \\
\hline Desa & Şartlı & $\begin{array}{l}\text { Hasılatın finansal } \\
\text { tablolara kaydedilmesi }\end{array}$ & $\begin{array}{l}\text { Maddi duran } \\
\text { varlıklarda yeniden } \\
\text { değerleme }\end{array}$ & $\begin{array}{l}\text { Stok değerleme } \\
\text { yöntemi }\end{array}$ & \\
\hline Dirit & Olumlu & & & & \\
\hline Hatek & Olumlu & $\begin{array}{l}\text { MDV ve Yatırım } \\
\text { Amaçlı } \\
\text { Gayrimenkullerin } \\
\text { Yeniden Değerlemesi }\end{array}$ & & & \\
\hline Krtek & Olumlu & Ticari Alacaklar & $\begin{array}{l}\text { Stoklar ve } \\
\text { Değerlemesi }\end{array}$ & $\begin{array}{l}\text { Hasılatın } \\
\text { Kaydedilmesi }\end{array}$ & \\
\hline Kords & Olumlu & $\begin{array}{l}\text { Hasılatın } \\
\text { Muhasebeleştirilmesi }\end{array}$ & $\begin{array}{l}\text { İşletme birleşmeleri } \\
\text { ve Şerefiye değer } \\
\text { düşüklüğü }\end{array}$ & & \\
\hline Luksk & Şartlı & $\begin{array}{l}\text { Arazi ve arsalar, } \\
\text { binalar, yeraltı ve } \\
\text { yerüstü düzenleri ile } \\
\text { yatırım amaçlı } \\
\text { gayrimenkullerin }\end{array}$ & & & \\
\hline
\end{tabular}


M. Erol Fidan 13/3 (2021) 1945-1969

\begin{tabular}{|c|c|c|c|c|}
\hline & & $\begin{array}{l}\text { gerçeğe uygun değer } \\
\text { tespiti }\end{array}$ & & \\
\hline Mndrs & Şartlı & Hasılatın Kaydedilmesi & $\begin{array}{l}\text { Ticari alacakların } \\
\text { geri kazanılabilirliği }\end{array}$ & $\begin{array}{l}\text { Stok Değerleme } \\
\text { Yöntemi }\end{array}$ \\
\hline Rodrg & Olumlu & Stokların Denetimi & Hasılatın Denetimi & \\
\hline Royal & Olumsuz & $\begin{array}{l}\text { Hâsılatın ve Maliyet } \\
\text { Hesaplarının } \\
\text { muhasebeleştirilmesi }\end{array}$ & & \\
\hline Sktas & Olumlu & Maddi Duran Varlıklar & Finansal Borçlar & \\
\hline Snpam & Şartlı & $\begin{array}{l}\text { Hasılatın } \\
\text { Muhasebeleştirilmesi }\end{array}$ & & \\
\hline Yatas & Olumlu & $\begin{array}{l}\text { TFRS } 15 \text { "Müşteri } \\
\text { Sözleşmelerinden } \\
\text { Hasılat" }\end{array}$ & $\begin{array}{l}\text { TFRS } 16 \text { "TFRS 16, } \\
\text { Kiralamalar" } \\
\text { standardının } \\
\text { uygulanması }\end{array}$ & \\
\hline Yünsa & Olumlu & $\begin{array}{l}\text { Hasılatın } \\
\text { Muhasebeleştirilmesi }\end{array}$ & & \\
\hline
\end{tabular}


M. Erol Fidan 13/3 (2021) 1945-1969

Tablo 10: 2018 Y11 Kilit Denetim Konuları

\begin{tabular}{|c|c|c|c|c|c|c|}
\hline Firma & Görüş & 1 & 2 & 3 & 4 & 5 \\
\hline Ateks & Şartlı & $\begin{array}{l}\text { Ticari Alacakların } \\
\text { Geri Kazanılabilirliği }\end{array}$ & $\begin{array}{l}\text { Stok değer düşüklüğüu } \\
\text { karşılığ }\end{array}$ & $\begin{array}{l}\text { MDV yeniden } \\
\text { değerleme } \\
\text { metodu }\end{array}$ & & \\
\hline Arsan & Olumlu & $\begin{array}{l}\text { Yatırım amaçlı } \\
\text { gayrimenkullerin } \\
\text { gerçeğe uygun değer } \\
\text { testleri }\end{array}$ & $\begin{array}{l}\text { Hasılatın finansal } \\
\text { tablolara } \\
\text { kaydedilmesi }\end{array}$ & $\begin{array}{l}\text { MDV yeniden } \\
\text { değerleme }\end{array}$ & & \\
\hline Blcyt & Olumlu & $\begin{array}{l}\text { Hasılatın } \\
\text { Kaydedilmesi }\end{array}$ & $\begin{array}{l}\text { MDV } \\
\text { Muhasebeleştirilmesi }\end{array}$ & & & \\
\hline Brko & Şartlı & & & & & \\
\hline Brmen & Şartlı & $\begin{array}{l}\text { MDV ve yatırım } \\
\text { amaçlı } \\
\text { gayrimenkullerin } \\
\text { değerlemesi }\end{array}$ & & & & \\
\hline Bossa & Olumlu & $\begin{array}{l}\text { Yatırım amaçlı ve } \\
\text { kullanım amaçlı } \\
\text { gayrimenkullerin } \\
\text { finansal tablolardaki } \\
\text { gösterimi ve } \\
\text { açıklanan önemli } \\
\text { bilgiler }\end{array}$ & $\begin{array}{l}\text { Yatırım teşviklerinin } \\
\text { finansal tablolardaki } \\
\text { gösterimi ve } \\
\text { açılanan önemli } \\
\text { bilgiler }\end{array}$ & $\begin{array}{l}\text { Borçlanma } \\
\text { maliyetlerinin } \\
\text { aktifleştirilmesi }\end{array}$ & & \\
\hline Dagi & Olumlu & Ticari Alacaklar & $\begin{array}{l}\text { MDV } \\
\text { Muhasebeleştirilmesi }\end{array}$ & $\begin{array}{l}\text { Hasılatın } \\
\text { Muhasebeleştiril } \\
\text { mesi }\end{array}$ & $\begin{array}{l}\text { Finansal } \\
\text { Borçlar }\end{array}$ & Stoklar \\
\hline Derim & Olumlu & $\begin{array}{l}\text { Ticari alacakların geri } \\
\text { kazanılabilirliği }\end{array}$ & & & & \\
\hline Deras & Şartlı & $\begin{array}{l}\text { Stoklar ve } \\
\text { değerlemesi }\end{array}$ & & & & \\
\hline Desa & Şartlı & $\begin{array}{l}\text { Hasılatın finansal } \\
\text { tablolara } \\
\text { kaydedilmesi }\end{array}$ & $\begin{array}{l}\text { Vergi cezalarına } \\
\text { ilişkin ayrılan } \\
\text { karşılıklar }\end{array}$ & $\begin{array}{l}\text { MDV yeniden } \\
\text { değerleme }\end{array}$ & $\begin{array}{l}\text { Stok } \\
\text { değerleme } \\
\text { yöntemi } \\
\end{array}$ & \\
\hline Dirit & Şartlı & Stoklar & & & & \\
\hline Hatek & Olumlu & Ticari Alacaklar & & & & \\
\hline Krtek & Olumlu & Ticari Alacaklar & $\begin{array}{l}\text { Stoklar ve } \\
\text { Değerlemesi }\end{array}$ & $\begin{array}{l}\text { Hasılatın } \\
\text { Kaydedilmesi }\end{array}$ & & \\
\hline Kords & Olumlu & $\begin{array}{l}\text { Hasılatın } \\
\text { muhasebeleştirilmesi } \\
\text { ve TFRS 15'in ilk } \\
\text { uygulaması }\end{array}$ & İşletme birleşmeleri & & & \\
\hline Luksk & Şartlı & $\begin{array}{l}\text { MDV ve yatırım } \\
\text { amaçlı } \\
\text { gayrimenkullerin } \\
\text { değerlemesi }\end{array}$ & & & & \\
\hline Mndrs & Olumlu & $\begin{array}{l}\text { Hasılatın } \\
\text { Kaydedilmesi }\end{array}$ & $\begin{array}{l}\text { Ticari alacakların geri } \\
\text { kazanılabilirliği }\end{array}$ & $\begin{array}{l}\text { Kıdem Tazminatı } \\
\text { Karşılığ }\end{array}$ & $\begin{array}{l}\text { Stok } \\
\text { Değerleme } \\
\text { Yöntemi }\end{array}$ & \\
\hline Rodrg & Olumlu & $\begin{array}{l}\text { Hasılatın } \\
\text { Muhasebeleştirilmesi }\end{array}$ & $\begin{array}{l}\text { Şüpheli Ticari } \\
\text { Alacaklar Karşılığı }\end{array}$ & & & \\
\hline
\end{tabular}


M. Erol Fidan 13/3 (2021) 1945-1969

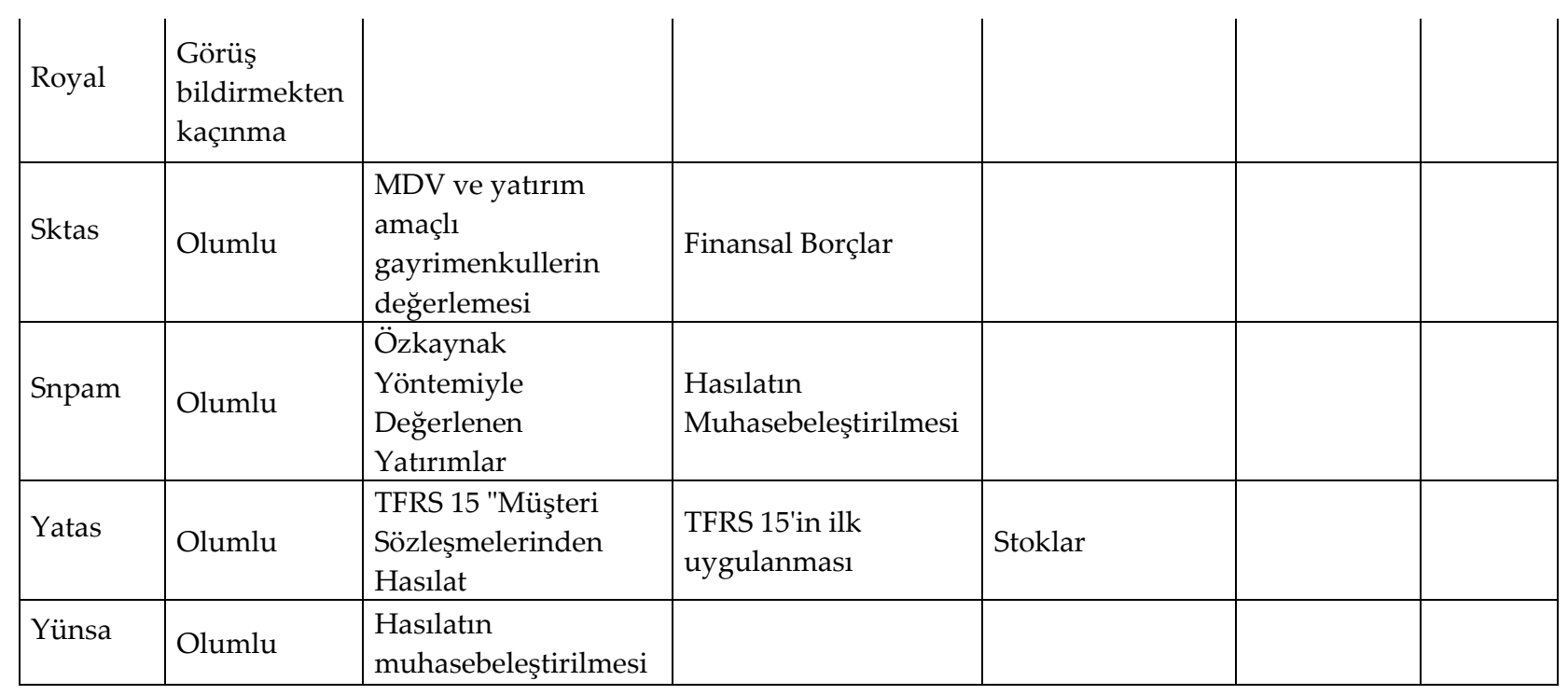


M. Erol Fidan 13/3 (2021) 1945-1969

Tablo 11: 2017 Y1lı Kilit Denetim Konuları

\begin{tabular}{|c|c|c|c|c|c|c|}
\hline Firma & Görüş & 1 & 2 & 3 & 4 & 5 \\
\hline Ateks & Olumlu & $\begin{array}{l}\text { Ticari Alacakların } \\
\text { Geri Kazanılabilirliği }\end{array}$ & $\begin{array}{l}\text { MDV yeniden } \\
\text { değerleme metodu } \\
\text { ile } \\
\text { muhasebeleştirilmesi }\end{array}$ & $\begin{array}{l}\text { Yatırım amaçlı } \\
\text { gayrimenkullerin } \\
\text { yeniden değerleme } \\
\text { metodu ile } \\
\text { muhasebeleştirilmesi }\end{array}$ & & \\
\hline Arsan & Olumlu & $\begin{array}{l}\text { Hasilatin finansal } \\
\text { tablolara } \\
\text { kaydedilmesi }\end{array}$ & & & & \\
\hline Blcyt & Olumlu & $\begin{array}{l}\text { Hasslatın } \\
\text { Kaydedilmesi }\end{array}$ & & & & \\
\hline Brko & Olumlu & & & & & \\
\hline Brmen & Olumlu & $\begin{array}{l}\text { MDV yeniden } \\
\text { değerleme metodu } \\
\text { ile } \\
\text { muhasebeleştirilmesi }\end{array}$ & Finansal Borçlar & & & \\
\hline Bossa & Olumlu & $\begin{array}{l}\text { Yatırım amaçlı ve } \\
\text { kullanım amaçlı } \\
\text { gayrimenkullerin } \\
\text { finansal tablolardaki } \\
\text { gösterimi ve } \\
\text { açıklanan önemli } \\
\text { bilgiler }\end{array}$ & $\begin{array}{l}\text { Akkardan Sanayi ve } \\
\text { Ticaret A.Ş.'nin ters } \\
\text { birleşme işleminin } \\
\text { muhasebeleştirilmesi }\end{array}$ & & & \\
\hline Dagi & Olumlu & Ticari Alacaklar & MDV & Finansal Borçlar & $\begin{array}{l}\text { Finansal } \\
\text { Borçlar }\end{array}$ & Stoklar \\
\hline Derim & Olumlu & $\begin{array}{l}\text { Arsa ve binaların } \\
\text { yeniden değerleme } \\
\text { modeline göre } \\
\text { muhasebeleştirilmesi }\end{array}$ & & & & \\
\hline Deras & & Yok & & & & \\
\hline Desa & Şartlı & $\begin{array}{l}\text { Vergi cezalarına } \\
\text { ilişkin ayrılan } \\
\text { karşılıklar }\end{array}$ & $\begin{array}{l}\text { MDV yeniden } \\
\text { değerleme }\end{array}$ & & & \\
\hline Dirit & Şartlı & Stoklar & Yeniden Değerleme & & & \\
\hline Hatek & Olumlu & $\begin{array}{l}\text { Yatırım Amaçlı } \\
\text { Gayrimenkuller - } \\
\text { MDV }\end{array}$ & Ticari Alacaklar & & & \\
\hline Krtek & Olumlu & Ticari Alacaklar & $\begin{array}{l}\text { Stoklar ve } \\
\text { Değerlemesi }\end{array}$ & $\begin{array}{l}\text { Hasılatın } \\
\text { Kaydedilmesi }\end{array}$ & & \\
\hline Kords & Olumlu & $\begin{array}{l}\text { Hasılatın } \\
\text { muhasebeleştirilmesi }\end{array}$ & & & & \\
\hline Luksk & Olumlu & $\begin{array}{l}\text { MDV yeniden } \\
\text { değerleme metodu } \\
\text { ile } \\
\text { muhasebeleştirilmesi }\end{array}$ & $\begin{array}{l}\text { Yatırım amaçlı } \\
\text { gayrimenkullerin } \\
\text { yeniden değerleme } \\
\text { metodu ile } \\
\text { muhasebeleştirilmesi }\end{array}$ & & & \\
\hline Mndrs & Olumlu & $\begin{array}{l}\text { Hasılatın } \\
\text { Kaydedilmesi }\end{array}$ & $\begin{array}{l}\text { Kıdem Tazminatı } \\
\text { Karşılığ } 1\end{array}$ & $\begin{array}{l}\text { Yatırım Amaçlı } \\
\text { Gayrimenkuller ve } \\
\text { Gerçeğe Uygun } \\
\text { Değer }\end{array}$ & & \\
\hline Rodrg & Olumlu & $\begin{array}{l}\text { Hasılatın } \\
\text { Muhasebeleştirilmesi }\end{array}$ & $\begin{array}{l}\text { Şüpheli Ticari } \\
\text { Alacaklar Karşılığ1 }\end{array}$ & & & \\
\hline Royal & $\begin{array}{l}\text { Görüş } \\
\text { bildirmekten } \\
\text { kaçınma }\end{array}$ & & & & & \\
\hline
\end{tabular}


M. Erol Fidan 13/3 (2021) 1945-1969

\begin{tabular}{|l|l|l|l|l|l|l|} 
Sktas & Olumlu & MDV & Finansal Borçlar & & & \\
\hline Snpam & Olumlu & yok & & & \\
\hline Yatas & Olumlu & $\begin{array}{l}\text { Hasılatın } \\
\text { Muhasebeleştirilmesi }\end{array}$ & $\begin{array}{l}\text { Stoklar ve } \\
\text { Değerlemesi }\end{array}$ & & & \\
\hline Yünsa & Olumlu & $\begin{array}{l}\text { Hasılatın } \\
\text { muhasebeleştirilmesi }\end{array}$ & & & & \\
\hline
\end{tabular}

